\title{
SOBRE LINGUAGENS, CORPOS E (CONTRA) POLÍTICAS: PRAXIOLOGIAS E LETRAMENTOS QUEER EM TEMPOS SOMBRIOS
}

\author{
ON LANGUAGES, BODIES AND (COUNTER) \\ POLITICS: QUEER PRAXIOLOGIES AND \\ LITERACIES IN DARK TIMES ${ }^{1}$
}

\section{Marco Túlio de Urzêda-Freitas*}

Resumo: Neste ensaio, que combina diferentes gêneros e vozes textuais, apresento uma reflexão situada sobre o potencial das praxiologias e letramentos queer na elaboração crítica destes tempos sombrios, marcados por crises sociais que têm estimulado a circulação de repertórios autoritários e neofascistas, assim como a banalização do mal e da vida no Brasil. Embasado por minhas memórias sobre alguns acontecimentos políticos que se deram no país entre 2013 e 2020, e movido pelos entrecruzamentos fomentados pela ideia de imundície praxiológica, proponho o estranhamento de um conjunto de atos de fala e oposições binárias que produziram e atravessam este cenário de crises. Em seguida, compartilho algumas premissas sobre o trabalho com letramentos queer, as quais são exemplificadas por duas experiências em um Instituto de Ensino Superior, na cidade de Goiânia-GO. Para concluir o ensaio, apresento a minha percepção dos letramentos queer como contrapolítica, isto é, como espaço de construção de resistências afetivas a projetos políticos institucionalizados que (re)produzem enquadres de autoritarismo, violência e morte.

Palavras-chave: Linguagem(ns). Corpos. (Contra)Políticas. Praxiologias queer. Letramentos queer.

\begin{abstract}
In this essay, which combines different textual genres and voices, I present a situated reflection on the potential of queer praxiologies and literacies in the critical elaboration of these dark times, marked by social crises that have stimulated the circulation of authoritarian and neo-fascist repertoires, as well as the banality of evil and life in Brazil. Based on my memories of some political events that took place in the country between 2013 and 2020, and influenced by the border movements fostered by the idea of praxiological filth, I propose the queering of a set of speech acts and binary oppositions that have produced and crossed this crisis scenario. Next, I share some considerations on the work with queer literacies, which are exemplified by two experiences at an Institute of Higher Education in the city of Goiânia-GO, Brazil. To conclude, I present my notion of queer literacies as counterpolitics, that is, as a site for the construction of affective resistances to institutionalized political projects that (re)produce frames of authoritarianism, violence, and death.
\end{abstract}

Keywords: Language(s). Bodies. (Counter)Politics. Queer praxiologies. Queer literacies.

\footnotetext{
* Doutor em Estudos Linguísticos pela Universidade Federal de Goiás (UFG). ORCID: https://orcid.org/0000-0001-7203-585X. E-mail: <marcotulioufcultura@gmail.com>.

${ }^{1}$ Agradeço às/aos colegas do grupo de pesquisa Transição pela leitura crítica do ensaio e pelas valiosas questões, apontamentos e diálogos compartilhados.
} 
“'Cause your world's in so much pain

'Cause your world is

"Cause your world is

Up in flames."

(Madonna, 2019a)

Figura 1: Manifestação contra o governo federal (2015)

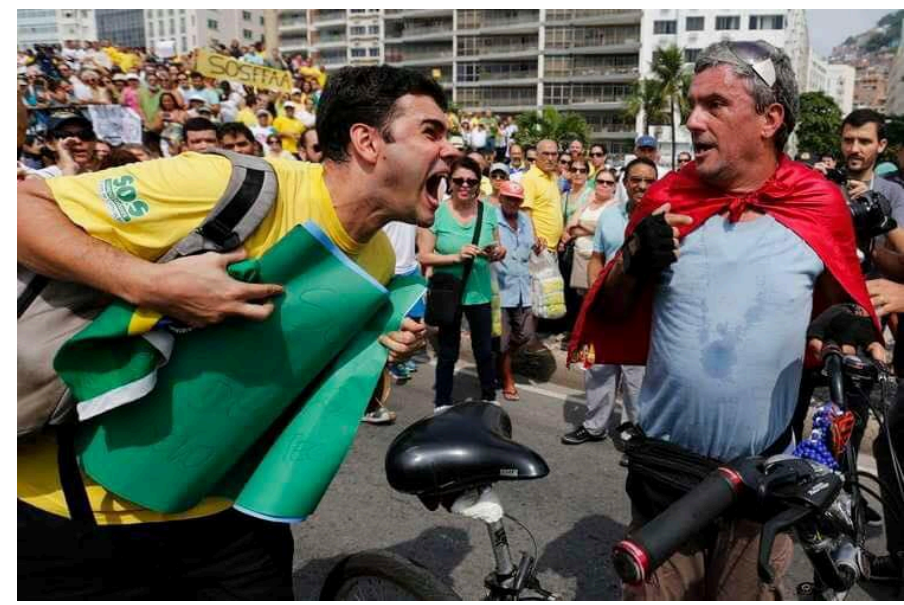

Fonte: Imagem extraída de G1 Rio. ${ }^{2}$

Os anos de 2015 e 2016 foram períodos de intensa crise política no Brasil. Uma crise que acirrou a polarização iniciada em junho de 2013 e dividiu xs brasileirxs em dois grupos. De um lado, estavam aquelxs que apoiavam o impeachment da então Presidenta da República, Dilma Rousseff, do Partido dos Trabalhadores (PT). Do outro lado, estavam aquelxs que se opunham ao que acreditavam ser um Golpe Parlamentar contra a Democracia. Essa divisão binária produziu uma série de conflitos em todo o país, como mostra a Figura 1, que retrata o momento em que um homem era hostilizado em uma manifestação contra o governo federal, no Rio de Janeiro.

Um dos eventos que mais me marcou, entre 2015 e 2016, foi a agressão sofrida por um casal que vestia camisetas vermelhas em um protesto contra o governo Dilma, em Curitiba. O caso foi mencionado por Marina Rossi em um texto publicado no site do El País ${ }^{3}$, em agosto de 2015:

Em Curitiba, um casal foi agredido porque vestia camisetas vermelhas, o que provocou a ira dos manifestantes anti-Dilma, que se caracterizaram por vestir roupas verde e amarela. A camiseta do rapaz, que tinha uma imagem de Che Guevara estampada, foi arrancada do seu corpo e, depois, incendiada. O rapaz tomou socos e chutes dos presentes. Ambos ficaram feridos e tiveram de ser escoltados pela polícia. (ROSSI, 2015, n.p.)

\footnotetext{
${ }^{2}$ Imagem disponível em: http://g1.globo.com/rio-de-janeiro/noticia/2015/03/manifestacao-anti-governo-reune-milhares-na-orlade-copacabana.html. Acesso em: 25 out. 2020.

${ }^{3}$ Ao longo do texto, utilizo o itálico para dar ênfase e as aspas para marcar ironia, metáfora ou citação literal.
} 
Como se pode notar, o principal motivo do embate foi a cor das camisetas que o casal vestia, possivelmente identificada como afronta pelxs manifestantes que vestiam as cores verde e amarelo - pelo fato de vermelho ser a cor predominante da bandeira petista. Inúmeros conflitos dessa natureza aconteceram pelo Brasil, inclusive em contextos ordinários, fora das paixões exacerbadas que se observavam nas manifestações contra o governo federal. Os casos de agressão motivados pela cor da roupa me marcaram tanto que, certo dia, me peguei retirando a camiseta vermelha que havia escolhido para ir trabalhar - eu adoro vermelho! - e tendo que pensar em qual camiseta poderia vestir. Fiquei um tempo sentado na cama, olhando fixamente para o guarda-roupa e pensando... Naquele momento, eu percebi que alguma coisa errada estava acontecendo. Afinal, em um Estado Democrático, ninguém deveria ter medo de sair às ruas vestindo determinada cor, pois um dos principais valores da Democracia é justamente a liberdade de escolha e manifestação. Naquele instante, eu percebi que estávamos, mais uma vez, entrando em uma fase delicada da nossa história.

A partir da consolidação do Golpe Parlamentar de 2016 (AVRITZER, 2016; BORBA, 2019; MELO; VAZ, 2018; SOUZA, 2016), uma teia de eventos controversos se desenrolou no cenário político brasileiro. O primeiro foi a abordagem parcial da Justiça na condução de investigações contra o ex-presidente Luiz Inácio Lula da Silva, do PT. Como mostram as reportagens da série Vaza Jato (BRASIL, 2019), a coletânea organizada por Proner et al. (2017) e as ponderações de Carvalho e Fonseca (2019), essa abordagem teve por objetivo impedir a candidatura de Lula nas eleições presidenciais de 2018 e pavimentar o caminho para a ascensão da extrema direita ao poder. Além disso, a condenação do ex-presidente poderia contribuir para consolidar o projeto de ódio ao PT e aos partidos de esquerda que se articulava desde 2013. Em 28 de outubro de 2018, Jair Bolsonaro, ex-militar da reserva e simpatizante declarado de políticas conservadoras e autoritárias, foi eleito Presidente do Brasil. A partir daí, começamos a testemunhar o desmantelamento de todo e qualquer projeto de cunho progressista que ainda nos restava. Hoje, temos que lidar com uma crise política mais acirrada que a de 2015-2016 e, ao mesmo tempo, com uma das maiores pandemias já vivenciadas pela humanidade. Ao todo, mais de 5.300 .000 pessoas foram infectadas e mais de 156.000 pessoas morreram por conta da Covid-194 até o momento no país, realidade que o atual governo tem feito questão de relativizar e, por vezes, ignorar.

Como em outros países, a nossa situação pandêmica fez com que os problemas sociais com os quais convivemos desde sempre se projetassem de modo visceral. As desigualdades historicamente construídas em torno de categorias como raça, classe, gênero, sexualidade e idade foram potencializadas a tal ponto que não há mais como fingir que elas não existem. As pessoas idosas são as que mais inspiram cuidados e as que mais necessitam de assistência hospitalar. As pessoas pobres e negras são as que mais morrem e sofrem com as restrições do isolamento social. O grupo mais desassistido pelo Estado, no tocante às políticas de saúde, são as comunidades indígenas. A violência contra as mulheres aumentou consideravelmente em muitos estados nos períodos de quarentena. Várias mulheres e homens cis e transgênerxs, que dependem das ruas para sobreviver, tiveram a sua renda comprometida. As drag queens, que geralmente atuam em contextos noturnos, foram impedidas de trabalhar devido ao fechamento

\footnotetext{
${ }^{4}$ Esses números têm como base as informações do Consórcio de Veículos de Imprensa, obtidas através de dados oficiais das secretarias estaduais de saúde, em 25 out. 2020.
} 
dos bares e boates. Entre outros problemas que, segundo Leandro Karnal (2020), revelam as consequências que as nossas escolhas produziram socialmente. Em âmbito global, Judith Butler (2020, n.p.) acredita que a pandemia fez com que a "brutalidade do capitalismo se [apresentasse] às claras, sem nenhum pudor”.

Embora sejamos frutos de uma sucessão de tempos sombrios e marcados por disputas violentas, acredito que o momento atual nos permite dizer que vivemos tempos mais sombrios que outros. Como Arendt (1987, p. 20), entendo que a obscuridade avança na medida em que "o âmbito público se [obscurece] e o mundo se [torna] tão dúbio que as pessoas [deixam] de pedir qualquer coisa à política além de que mostre a devida consideração pelos seus interesses vitais e liberdade pessoal”. Ainda com base na autora (ARENDT, 2000), acredito que a vida se torna mais sombria quando o mal banal se impõe como elemento estruturante das relações sociais, isto é, quando os sujeitos começam a se engajar sistematicamente na prática de atos perversos de forma irrefletida, como se estivessem cumprindo um mero dever burocrático. O efeito mais pernicioso dessa realidade é que, ao tornar-se palco da banalização do mal, a sociedade passa a mobilizar repertórios que performam a banalização da vida, em sentido mais amplo, o que colabora para a construção "legal” de cenários de violência, destruição e morte (MBEMBE, 2019). No contexto brasileiro, essa dinâmica obscura pode ser observada tanto no campo político, uma vez que temos assistido à falência gradual do nosso precário sistema democrático, quanto no campo da existência, no sentido de estarmos expostxs a um amplo campo de forças e práticas violentas naturalizadas. Esse enquadre de guerra, como diria Butler (2009), tem produzido em nós uma insegurança crônica generalizada, fazendo-nos experimentar, cotidiana e repetidamente, o medo de ter os nossos direitos e as nossas vidas depredadas.

A onda de obscuridade que tem se instalado no Brasil e em outras partes do mundo é corajosamente explorada por Madonna (2019a) em seu álbum Madame X. Na música Dark ballet - Balé sombrio -, a cantora propõe uma recontextualização da morte de Joana D'Arc sob a ótica dos tempos atuais, de modo a traçar um paralelo entre as duas épocas. A letra parece materializar os pensamentos de uma Joana D’Arc contemporânea, formada por múltiplas vozes, que evoca repertórios do passado para se posicionar em relação ao presente. Em certo momento, declara: "Elxs são tão inocentes. Elxs acham que não estamos cientes dos seus crimes. Nós sabemos. Apenas não estamos prontxs para agir”5. O videoclipe da música (MADONNA, 2019b) nos permite entender que o pronome elxs remete tanto àquelxs que condenaram Joana D’ Arc à fogueira quanto àquelxs que atualmente preparam o cenário para a execução de determinados corpos. O que se pretende dizer é que a história se repete. No videoclipe, Joana D’Arc é uma mulher transexual, negra e HIV positiva, representação que se coloca como símbolo de um mundo “em chamas”, como diz a epígrafe do ensaio. No documentário O Mundo de Madame X, Madonna (2019c) conclui: “Dark ballet é o tipo de dança que todxs estamos dançando neste momento”.

\footnotetext{
${ }^{5}$ As citações originalmente escritas em inglês são de minha autoria.
} 
Figura 2: Cena do videoclipe da música Dark ballet

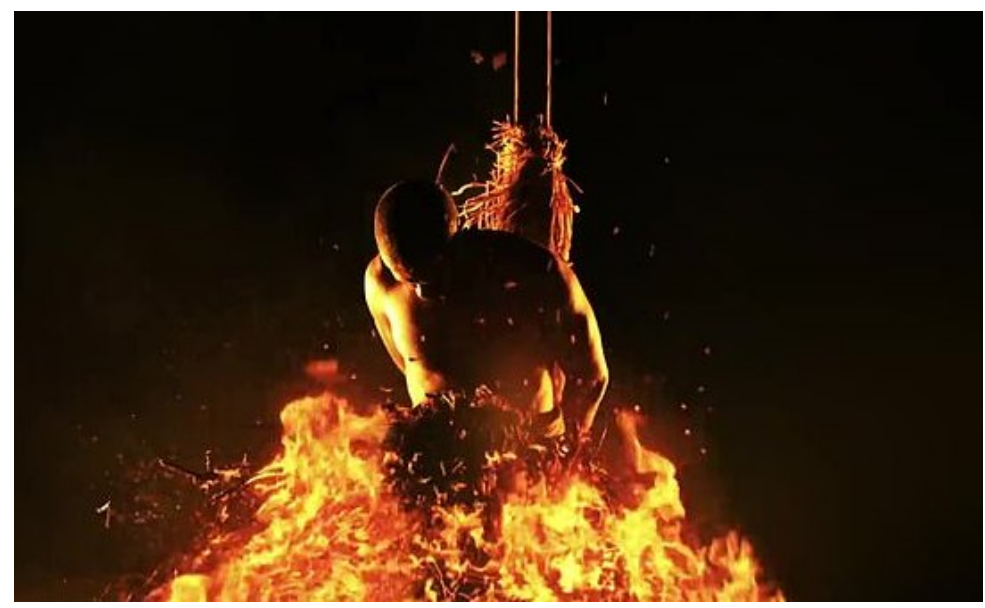

Fonte: Imagem extraída do videoclipe. ${ }^{6}$

No Brasil, entendo que esse Balé sombrio começou a se construir discursivamente no dia 17 de abril de 2016, durante a sessão da Câmara dxs Deputadxs que aprovou a instauração do processo de impeachment contra a então Presidenta Dilma Rousseff. Aqui, me refiro, mais especificamente, ao momento em que Jair Bolsonaro, na época deputado federal, dedicou o seu voto - favorável ao impeachment/Golpe - a um sujeito reconhecido pela Justiça brasileira como torturador da Ditadura Civil-Militar: "Pela memória do coronel Carlos Alberto Brilhante Ustra, o pavor de Dilma Rousseff"' . A classificação do homenageado como o pavor de Dilma Rousseff deve-se ao fato de Ustra ter sido um dos militares que torturaram a ex-presidenta quando ela esteve presa. O silêncio do Estado, das instituições e de grande parte dxs brasileirxs frente àquele ato de fala injurioso (BUTLER, 1997) teve como efeito a legitimação do mal banal (ARENDT, 2000) como forma não apenas de fazer política, mas também de conduzir as relações sociais no Brasil. Na contramão da injúria perpetrada pelo colega, o então deputado federal Jean Wyllys dedicou o seu voto - contrário ao impeachment/Golpe - “[à] população LGBT, [ao] povo negro exterminado nas periferias, [aos] trabalhadores da cultura, [aos] sem teto, [aos] sem terra"8. Em seguida, cuspiu na direção do ex-militar da reserva. Foi a partir desse complexo arranjo de performances sociodiscursivas que a livre circulação de repertórios neofascistas e a reiterada articulação de protestos antifascistas ganharam espaço em nossa história recente. Com base em Foucault (1980), pode-se dizer que, naquele contexto, tivemos a oportunidade de observar como operam as relações de poder e como se formam as resistências.

\footnotetext{
${ }^{6}$ Imagem disponível em: https://www.youtube.com/watch?v=6Uagw4zser8. Acesso em: 25 out. 2020.

${ }^{7}$ Trecho da fala integralmente disponível em: https:/www.youtube.com/watch?v=YvC1hdOh264. Acesso em: 25 out. 2020.

${ }^{8}$ Trecho da fala integralmente disponível em: https://www.youtube.com/watch?v=BkgXS8iKnWY. Acesso em: 25 out. 2020.
} 
Figura 3: Reação de Jean Wyllys ao voto injurioso de Jair Bolsonaro (2016)

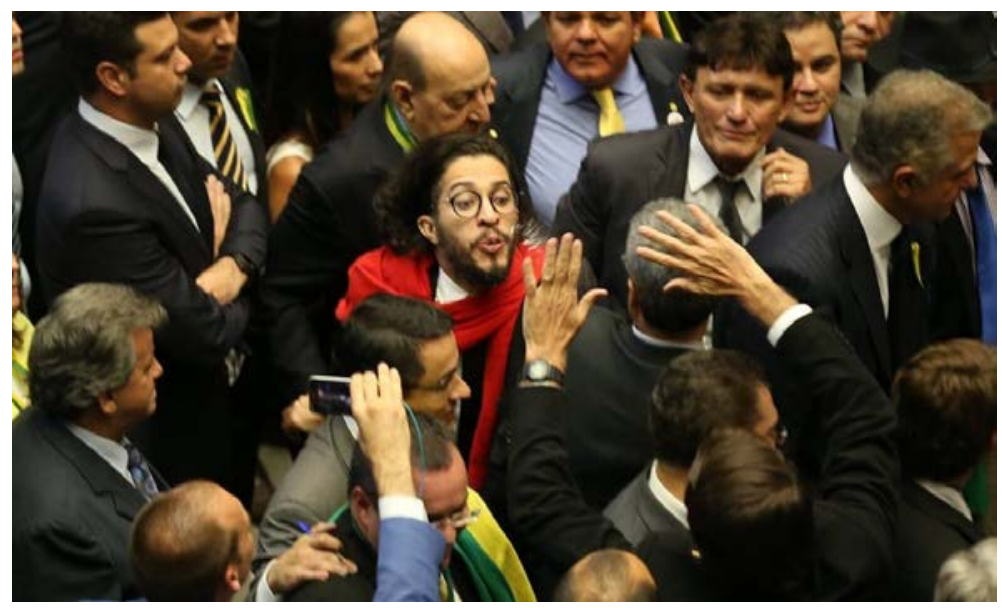

Fonte: Imagem extraída de O Globo. ${ }^{9}$

Atualmente, vivemos sob a ameaça de uma obscuridade que se revela, sobretudo, nos efeitos dos atos de fala, das compreensões binárias e das políticas instauradas pelo governo de Jair Bolsonaro, as quais ecoam uma aliança entre valores neoliberais e neopentecostais, além de flertarem muito proximamente com repertórios neofascistas. Com base na discussão de Sousa-Santos (2007), acredito que o atual governo se apresenta como um exemplo dos chamados fascismos sociais, entendidos como regimes sociais pluralistas que se mantêm em contextos democráticos através de relações de poder amplamente desiguais. Uma de suas principais características "é a segregação social dos excluídos por meio de uma cartografia urbana dividida em zonas selvagens e zonas civilizadas”, divisão que geralmente se converte em um “critério geral de sociabilidade”, isto é, “em um novo espaço-tempo hegemônico que perpassa todas as relações sociais, econômicas, políticas e culturais” (SOUSA-SANTOS, p. 80). No caso do governo Bolsonaro, o fascismo social também se expressa por meio do que poderíamos chamar de um oportunismo sádico. Afinal, estamos falando de um projeto de poder que tem se aproveitado do pânico em relação à pandemia da Covid-19 para instaurar uma batalha pelo significado de termos/princípios caros ao bem-estar social e ao Estado Democrático de Direito, como liberdade, censura, justiça, verdade e democracia.

Como se trata de uma batalha que se materializa, em grande parte, via discurso e que envolve uma organização dos corpos em torno de múltiplas textualidades, sinto-me instigado a refletir sobre o potencial das praxiologias ${ }^{10}$ e letramentos queer na elaboração crítica deste cenário de disputas. Inspirado por autorxs como Jagose (1996), Sullivan (2003), Louro (2004), Preciado (2011) e Miskolci (2012), entendo as praxiologias queer como repertórios plurais, moventes e, por vezes, contraditórios de conhecimento que se encontram no objetivo de construir propostas analíticas da normalização. Não se trata de visibilizar identidades marginalizadas

\footnotetext{
${ }^{9}$ Imagem disponível em: https://oglobo.globo.com/brasil/bolsonaro-nega-insultos-jean-wyllys-se-diz-alvo-de-perseguicaopolitica-20439233. Acesso em: 25 out. 2020.

${ }^{10}$ Neste ensaio, o termo praxiologia é utilizado como uma alternativa à palavra teoria e, consequentemente, ao binarismo teoriaprática, na medida em que remete a todos os saberes e ações que nos constituem em nosso fazer (onto)epistemológico.
} 
ou de produzir um sujeito protagonista para um movimento. O que se propõe é analisar como e por que determinados corpos e performances se tornam marginalizadas e como esse processo interpela os sujeitos que participam das tramas sociais. Preciado (2011, p. 18) sugere que pensemos em uma política das multidões queer, que articule "uma posição crítica a respeito dos efeitos normalizantes e disciplinares de toda formação identitária”, operando em favor de "uma desontologização do sujeito". Obviamente, os movimentos identitários ainda se mostram relevantes - e necessários - para certos grupos, pois vivemos em um mundo atravessado por desigualdades, interdições e violências. No entanto, é preciso reconhecer que as disputas identitárias também estão sujeitas à (re)produção de discursos que reiteram normas regulatórias, excludentes e punitivas de ser e estar no mundo. Daí o esforço das praxiologias queer de pensar em caminhos pós-identitários para a vida social.

A meu ver, esses caminhos partem da ideia de que nada existe fora do discurso, o que significa dizer que nada existe fora da cultura, da história, da ideologia e da linguagem. Assim, tenho evitado quaisquer tentativas de essencialização dos corpos, pois acredito que essas materialidades são discursivamente (re)produzidas (BUTLER, 1993) e estão sempre à deriva, em um constante processo de tornar-se. No que se refere às identidades, tendo a concordar com Butler (1990), no sentido de compreendê-las como frutos de performances repetidamente encenadas pelos sujeitos no mundo social. Trata-se de repertórios ficcionais dos quais nos valemos para dizer quem somos - ou acreditamos ser - em um dado contexto, que também está sempre em movimento. A desconstrução de binarismos identitários, tais como homem-mulher e heterossexual-homossexual, pode ser uma estratégia profícua para o desvelamento dessa ficcionalidade, na medida em que, sob a ótica de Derrida (1973 [1967]), ela possibilita explicitar os jogos de presença e ausência que constituem esses binarismos, mostrando como os seus elementos são interdependentes e como as suas classificações dicotômicas produzem hierarquias e mascaram outras possibilidades de significação. Nessa perspectiva, acredito que as praxiologias queer se deslocam para além das performances de gênero e sexualidade, que constituem o seu território fundador, podendo ser evocadas para desconstruir quaisquer categorias, eventos, performances ou práticas sociais que se mantêm através de mecanismos discursivos e binários.

O entrecruzamento das praxiologias queer com os estudos sobre letramentos se dá justamente no interesse de ambos os campos pelo discurso e pela produção de significados. A primeira questão que eu gostaria de ressaltar é a minha escolha pelo uso da palavra letramento sempre no plural, o que reflete uma compreensão situada e movente das práticas e eventos de letramento, bem como das materialidades e recursos que diferentes espaços de leitura podem mobilizar. Sendo assim, na esteira de autorxs como Souza (2011), Rocha (2013), Urzêda-Freitas (2018) e Rezende (2020), entendo os letramentos como práticas discursivas que resultam de eventos mediados por múltiplos repertórios textuais além do texto escrito, como a fala, a música, as propagandas, os filmes, os corpos, as performances e a realidade social. Como pondera Rezende (2020, p. 10), letramentos são experiências ontoepistêmicas nas quais “[l]íngua, corpo e lugar se fundem na enunciação e na construção dos significados”. Isso porque, de acordo com a autora, são experiências pluritópicas e pluriversas que "consideram a diferenciação colonial e as feridas coloniais", o que as torna "uma travessia [não normatizada] no transcurso da poética da vida em constante fazer” (REZENDE, 2020, p. 14). Uma vez compreendidos como práticas que extrapolam a leitura e a escrita formais, pode-se dizer que os letramentos não se restringem à escola, expandindo-se para uma série de outros contextos pelos quais os sujeitos transitam, 
como a rua, o trabalho, o comércio, a igreja e a própria casa. Para mencionar o termo sugerido por Kleiman (1995), todos esses contextos se apresentam como agências de letramento.

Um dos princípios que informam a minha compreensão dos letramentos queer é que a linguagem não apenas descreve, mas (re)produz a realidade à qual se refere. Ao dizer, nos valemos de repertórios já disponíveis para conferir existência ao mundo social e material, o que se dá por meio de repetições com potencial transgressivo, isto é, de repetições que, não podendo se concretizar de forma exata, abrem espaço para a circulação de outros repertórios de sentido (ROCHA, 2013). Esse princípio, referido por Derrida (1977) como iterabilidade, permite uma compreensão da linguagem como performance, a qual se funda na ideia de que as nossas práticas de linguagem performam sentidos que apontam para quem somos - ou acreditamos ser - no mundo e que (re)constroem esse mundo no ato da performance. Nessa linha de raciocínio, entendo os letramentos queer como práticas discursivas situadas que têm por objetivo colocar em xeque repertórios estanques de significação e concepções binárias sobre os corpos, os sujeitos, as identidades e o mundo social, de modo a construir um quadro de propostas analíticas da normalização. Os corpos acabam recebendo uma atenção especial nesse processo, uma vez que o corpo ocupa uma posição de destaque nos enquadres de disputa, afinal, é "nele [que] estão inscritas as regulações sociais” (PINTO, 2007, p. 12). Seja qual for a disputa, é dos corpos que se trata e é para os corpos que se destinam as forças que ela (re)produz.

A construção de propostas analíticas queer envolve o reconhecimento de que essas praxiologias comumente emergem de territórios (onto)epistemologicamente fronteiriços, marcados pelo diálogo entre diferentes áreas do conhecimento e/ou lógicas de saber-existência. Ao problematizarem visões que defendem a pureza linguística e uma suposta necessidade de higienização verbal, Borba e Lopes (2018, p. 259) sugerem o uso de escrituras imundas como forma de "[tirar] a língua de um lugar de pureza e lhe [contaminar] com usos mundanos, políticos e éticos”. Assim, propostas como o uso do $x$ no lugar da marcação binária de gênero - a qual adoto neste ensaio - se configuram como formas de imundície verbal, que "desafiam o purismo linguístico, embaralham os binarismos do nível sistêmico (oralidade/escrita; significado/ significante, etc.), contaminam a língua com uma agenda política e assim tiram-na de sua zona asséptica de conforto” (BORBA; LOPES, 2018, p. 260). Inspirado por essa proposta, acredito que a produção de saberes queer esteja respaldada pelo que poderíamos chamar de imundície praxiológica, que seria, basicamente, uma postura que fomenta o entrecruzamento de múltiplos repertórios (onto)epistemológicos na construção de conhecimentos. Parafraseando Borba e Lopes (2018), ao entrelaçar vozes e perspectivas diversas, oriundas de diferentes lógicas de saber-existência, desafia-se o purismo científico, embaralham-se as distinções e as hierarquias praxiológicas, contamina-se a ciência com uma agenda política e subversiva, e tiramo-nos de nossas zonas estagnadas de conforto. Tal como argumenta Moita Lopes (2020), o que se propõe é uma “total promiscuidade das disciplinas” como forma de criar inteligibilidades críticas sobre e para a vida social contemporânea.

Neste ponto, cabe, então, perguntar: como as praxiologias e letramentos queer podem nos ajudar a compreender - e a viver - em tempos mais sombrios que outros? Acredito que a maior contribuição desses repertórios em nosso atual contexto é que eles nos possibilitam transitar por diferentes espaços para elaborar o que está acontecendo e construir praxiologias alternativas em nosso fazer (onto)epistemológico. Tais repertórios nos permitem compreender a 
realidade obscura em que vivemos como um texto e, por assim dizer, como um dado ficcional, o que implica reconhecê-la como resultado de um conjunto de mecanismos e performances discursivas que podem ser estranhadas. A palavra estranhar está relacionada a uma das possíveis traduções do termo queer para o português do Brasil - estranho -, remetendo-se à intenção de colocar sob suspeita a aparente naturalidade de alguns eventos que marcam estes tempos sombrios. O meu estranhar envolve, portanto, o reconhecimento da fabricação da nossa realidade atual e, consequentemente, dos mecanismos discursivos que possibilitaram a sua emergência. Dentre esses mecanismos, me concentrarei em um grupo de atos de fala e oposições binárias que contribuíram para produzir essa obscuridade e que têm exercido um papel significativo em sua manutenção.

Com base na visão performativa da linguagem (AUSTIN, 1975), compreendo os atos de fala como enunciados que não apenas descrevem o dito "real", mas produzem efeitos sobre ele. Essa é uma noção primordial para se entender o conceito de performatividade, que remete à propriedade da linguagem de produzir o que ela supostamente descreve no ato da performance discursiva (BORBA, 2014; BUTLER, 1997; PINTO, 2007). Como pondera Rocha (2013, p. 44), as palavras não são formas para a realização de ações: "as palavras são a própria ação". Outro conceito importante é que a linguagem é um fenômeno indexical, isto é, que "o signo sempre aponta para o movimento dinâmico do significado na sócio-história” (FREITAS; MOITA LOPES, 2019, p. 151). O meu uso desse conceito se relaciona, mais especificamente, à ideia de indexicalidade social, segundo a qual a linguagem sempre aponta para determinadas posições, qualidades e/ou fluxos, permitindo a identificação de diferentes hierarquias e vinculações socioidentitárias (BUCHOLTZ; CURTIN, 2009; HALL, 2010; RITCHIE, 2017). Tal ideia nos leva a compreender os atos de fala como atos de corpo (PINTO, 2002), uma vez que os enunciados precisam do corpo físico e socioculturalmente marcado - e ritualizado - para cumprir a sua trajetória indexical e performativa. Nas palavras de Pinto (2007, p. 106), "a presença material e simbólica do corpo na execução do ato [de fala] é uma marca que se impõe no efeito linguístico”.

A escolha do grupo de atos de fala e oposições binárias focalizado a seguir se deu a partir das minhas memórias sobre alguns acontecimentos políticos (CARVALHO, 2019) que se passaram no Brasil entre os anos de 2013 e 2020. Dessa forma, este ensaio se insere em uma perspectiva das experiências de vida como projeto legítimo de conhecimento, na medida em que reflete uma busca de sentido "centrada num aspecto particular de nós mesmos ou do nosso ser em relação com o mundo" (JOSSO, 2004, p. 99). Em um plano ainda mais pessoal, apresento, aqui, uma elaboração material/escrita das inquietações que têm me acompanhado nos últimos 7 anos, desde que comecei a perceber que "algo no nosso tecido social começa[va] a mudar” (DEMOCRACIA EM VERTIGEM, 2019, n.p.). Trata-se, portanto, de uma construção textual e praxiologicamente situada (HARAWAY, 1995 [1988]), a qual se alinha com perspectivas contemporâneas da linguística aplicada (LA). Para Moita Lopes e Fabrício (2019), xs pesquisadorxs em LA devem buscar uma proximidade crítica com os seus estudos, o que significa localizar-se ontologicamente neles, já "que modos de falar, sentir, sofrer, gozar etc. são inseparáveis do ato de pesquisar” (MOITA LOPES; FABRÍCIO, 2019, p. 713). Desse modo, as reflexões compartilhadas neste ensaio, especialmente as que serão focalizadas a partir de agora, resultam do entrecruzamento de vários repertórios semióticos, textuais, discursivos e praxiológicos que compõem a minha proximidade crítica com os eventos em destaque e com o meu próprio fazer acadêmico. 
Figura 4: Manifestação “anticorrupção” no Congresso Nacional (2013)

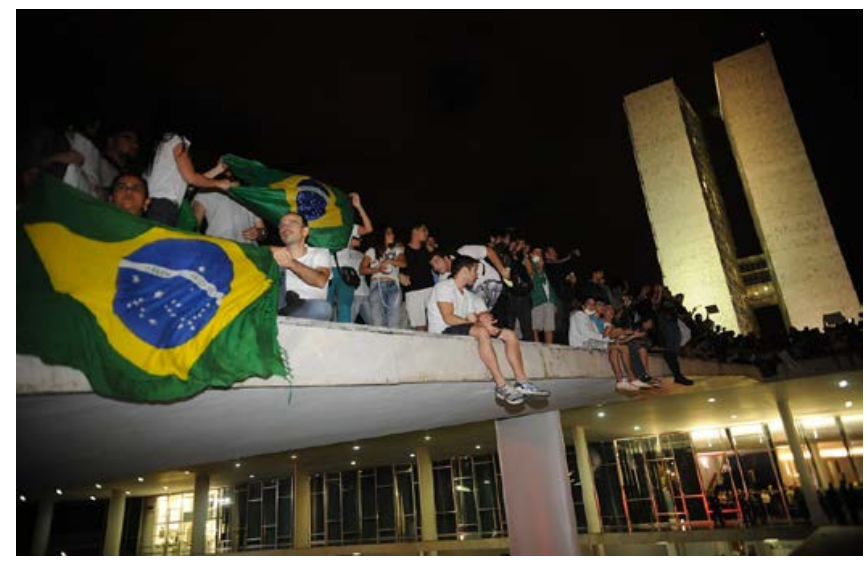

Fonte: Imagem extraída de Wikipedia. ${ }^{11}$

Os atos de fala que produziram a obscuridade que atualmente assola o Brasil derivam de três momentos de uma crise política que marca a nossa história recente: a revolta das classes dominantes ${ }^{12}$ contra o projeto de poder dos governos petistas (2013-2015); a articulação e consumação do Golpe Parlamentar contra Dilma Rousseff (2015-2016); e a eleição de Jair Bolsonaro para a Presidência da República (2018). No tocante ao primeiro momento, um dos atos de fala que mais marcaram o período foi Não é por vinte centavos!, que começou a ser proferido, sobretudo pelas elites e classes médias, durante as manifestações contra o aumento de $\mathrm{R} \$ 0,20$ no preço da passagem de ônibus, em junho de 2013. A repetição desse ato de fala fez com que as reivindicações das classes populares fossem gradativa e sutilmente deslegitimadas e apagadas daquele cenário de protesto, que passou a ter a voz das classes dominantes como protagonista de uma suposta e pitoresca luta contra a corrupção. O que se pretendia dizer era que o objetivo daquela revolta "popular” não era contestar o novo preço do transporte coletivo, mas protestar contra questões de maior amplitude social, como a corrupção institucionalizada da política brasileira. Melo e Vaz (2018, p. 25) argumentam que esse deslocamento confuso de vozes e demandas, marcado pela intervenção conservadora das elites e classes médias, evidenciam a "disputa sobre o sentido" que atravessou as Manifestações de Junho e que serviu de base para futuras instabilidades democráticas no país.

Outro ato de fala bastante simbólico do momento, e que se converteu em uma das principais marcas discursivas das manifestações “anticorrupção”, foi O gigante acordou!. O objetivo da insistente repetição desse enunciado era construir a ideia de que, após um longo período de negligência, xs brasileirxs haviam se tornado conscientes dos jogos espúrios que estruturam a política nacional. Ambos os atos de fala em destaque - Não é por vinte centavos! e O gigante acordou! - tiveram como principal efeito a mobilização de repertórios discursivos que possibilitaram a articulação do Golpe Parlamentar de 2016 (AVRITZER, 2016; MELO; VAZ, 2018;

\footnotetext{
${ }^{11}$ Imagem disponível em: https://pt.wikipedia.org/wiki/Jornadas_de_Junho. Acesso em: 25 out. 2020.

${ }^{12}$ Neste ensaio, os termos classes dominantes e classes populares são evocados para designar os grupos sociais cujos interesses políticos, econômicos e culturais são, respectivamente, garantidos ou priorizados, e ignorados ou relativizados pelas políticas de Estado.
} 
SOUZA, 2016). Além disso, tais enunciados fomentaram a construção de um nacionalismo exacerbado e agressivo, que, por sua vez, resultou na instituição arbitrária de três inimigos da pátria: o governo Dilma, o PT e os partidos de esquerda. Considerando o fúnebre silêncio das ruas e das "vozes anticorrupção” frente às práticas corruptas mobilizadas após a destituição de Dilma Rousseff - as quais incluem o governo de Jair Bolsonaro -, pode-se afirmar que aquelas manifestações nunca foram contra a corrupção, mas contra o projeto de poder dos governos petistas, que, apesar das alianças e movimentos eticamente questionáveis, promoveram abalos significativos na ordem hegemônica que sempre estruturou a realidade social brasileira. Como ressaltam Melo e Vaz (2018, p. 29), o lugar de guerreiro da integridade levou as classes dominantes a acreditarem que "lutava[m] pelo bem comum e não porque estivesse[m] incomodada[s] com a perda de privilégios materiais e simbólicos”.

Em relação ao segundo momento da nossa história recente, quatro atos de fala estão intimamente relacionados à articulação e consumação do Golpe Parlamentar de 2016: Dilma burra; Dilma vadia; O PT destruiu o país; e Fora Dilma! Fora PT!. A enunciação dos dois primeiros atos de fala possibilitou a mobilização de repertórios que atestavam a incapacidade de gestão e a irresponsabilidade política da então Presidenta, o que se deu por meio de argumentos fortemente enraizados em prerrogativas sexistas e misóginas. Sobre essa questão, Borba (2019, p. 172) explica que dizeres como Dilma vadia, amplamente proferidos na época, se configuram como "signos injuriosos que não endereçavam a administração do país, mas questões de gênero e sexualidade”, o que nos permite compreender "a circulação do ódio e a configuração de certas (in)sensibilidades políticas”. Por sua vez, o terceiro ato de fala - O PT destruiu o país - motivou a produção de repertórios que levaram grande parte da população brasileira a eleger o PT como o único responsável pela crise econômica que o país enfrentava. Ao compreender a Presidenta Dilma como incapaz e irresponsável politicamente, e tendo em mente a ideia de que o seu partido destruiu o Brasil, nada parecia mais lógico e cabível do que fazer "um grande acordo nacional”"13 e destituí-la do cargo. Esse foi um dos efeitos mais notáveis do último ato de fala - Fora Dilma! Fora PT! -, que se tornou uma espécie de "grito popular” que materializava o suposto desejo político da nação.

Além de produzir as condições sociodiscursivas para a consolidação do Golpe de 2016, que representou "um golpe nas ilusões democráticas geradas pelos limites próprios da ordem burguesa (e de sua democracia)” (BRAZ, 2017, p. 89), a reiterada mobilização desses quatro atos de fala produziu uma resistência coletiva aos partidos de esquerda e a repertórios políticos progressistas. Foi esse arranjo perverso e leviano que possibilitou à extrema direita sair do armário (MESSENBERG, 2017) e movimentar o seu conservadorismo reacionário (BRAZ, 2017) na produção de "uma nova hegemonia que [criasse] condições ideais para a reprodução dos interesses capitalistas num cenário novo", o qual requeria a construção de "um novo bloco de poder" (BRAZ, 2017, p. 94, grifos do autor).

\footnotetext{
${ }^{13}$ Estes termos foram utilizados pelo ex-presidente da Transpetro, Sérgio Machado, em uma conversa com o então senador licenciado Romero Jucá, a qual evidencia a intenção política por trás da articulação do impeachment de Dilma Rousseff. A íntegra da conversa encontra-se disponível no seguinte endereço: https://www1.folha.uol.com.br/poder/2016/05/1774018-em-dialogos-gravados-jucafala-em-pacto-para-deter-avanco-da-lava-jato.shtml. Acesso em: 25 out. 2020.
} 
Figura 5: Julgamento do impeachment de Dilma Rousseff (2016)

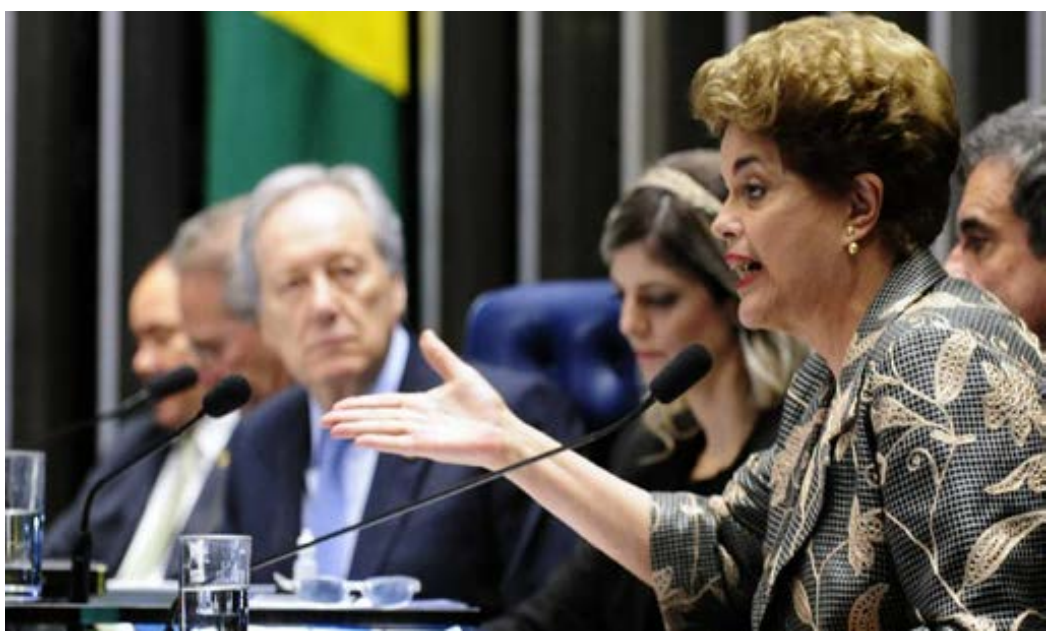

Fonte: Imagem extraída de El País. ${ }^{14}$

Entre a consumação do Golpe Parlamentar que destituiu Dilma Rousseff e a campanha eleitoral de 2018, um evento contribuiu, sobremaneira, para a vitória de Jair Bolsonaro: a prisão de Lula. Como já mencionado, essa prisão resultou, em grande parte, da abordagem parcial da Justiça brasileira, materializada na figura do então juiz Sérgio Moro, frente a investigações contra o ex-presidente. Naquele meio-tempo, atos de fala como Lula ladrão! foram agregados aos já populares O PT destruiu o país e Fora PT!, de modo a produzir uma imagem de "clamor popular" contra o suposto partido mais corrupto de todos os tempos. Carvalho e Fonseca (2019) entendem a prisão de Lula e seus eventos correlatos como acontecimentos políticos respaldados pelas mídias tradicionais e que apresentam dimensões de violência e notória parcialidade. Com base na coletânea de Proner et al. (2017), xs autorxs argumentam que esses acontecimentos tiveram “motivações mais políticas do que jurídicas” e que o seu real objetivo era interferir "no processo eleitoral de 2018, que teve Lula em primeiro lugar em todas as pesquisas de intenção de votos mesmo após seu encarceramento” (CARVALHO; FONSECA, 2019, p. 101). Com a prisão do ex-presidente, a chapa do PT foi composta pelo professor da Universidade de São Paulo (USP) e ex-prefeito de São Paulo, Fernando Haddad, e pela jornalista e ex-deputada federal, Manuela d’Ávila, mudança que repercutiu negativamente na campanha eleitoral do partido.

\footnotetext{
${ }^{14}$ Imagem disponível em: https://brasil.elpais.com/brasil/2016/08/30/politica/1472521971_061763.html. Acesso em: 25 out. 2020.
} 
Figura 6: Interrogatório do ex-presidente Lula em Curitiba (2018)

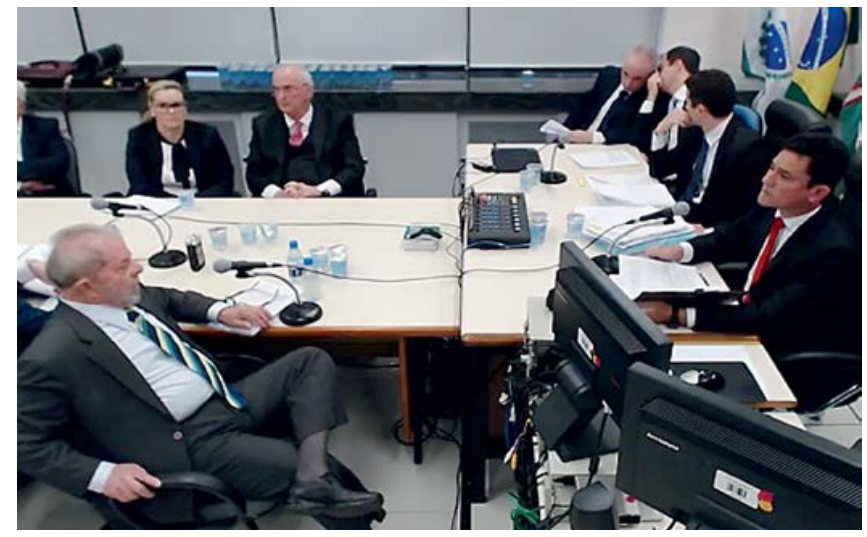

Fonte: Imagem extraída de Veja. ${ }^{15}$

No que diz respeito à eleição de Jair Bolsonaro para a Presidência da República, o ato de fala mais representativo do momento foi o seu slogan de campanha: Brasil acima de tudo. Deus acima de todos. A primeira parte do ato, Brasil acima de tudo, que faz alusão ao mote nazista Deutschland über alles - Alemanha acima de tudo -, contribuiu para consolidar o projeto nacionalista iniciado nas manifestações de 2013, reforçando as performances identitárias que se esperavam dxs brasileirxs ditxs patriotas e estigmatizando as que destoavam daquele padrão arbitrariamente imposto. Em diálogo com Moll Neto (2017, p. 289, grifos meus), pode-se dizer que essa visão dicotômica se apresentou - e ainda se apresenta - como uma "fronteira verbalizada, que opõe o que é benigno [patriotas] e o que é maligno [não patriotas] em vários níveis”, mostrando-se, por assim dizer, "fundamental para definição da concepção de nação [que] sustenta um projeto político que busca ser hegemônico”. Por sua vez, a segunda parte do ato de fala - Deus acima de todos - teve como efeito a adesão de uma parcela expressiva da dita comunidade cristã brasileira, especialmente de grupos evangélicos, à campanha de Jair Bolsonaro, cujo plano de governo refletia os seus ideais conservadores e excludentes. Embasada por uma concepção de discurso como performance, Guirado (2019, p. 5) entende o slogan Brasil acima de tudo. Deus acima de todos. como a materialização de um compromisso firmado pela campanha eleitoral do então candidato, a qual é definida como "um ator concreto, um termo totalizante e de certo modo abstrato, [que] tem vontade e ações próprias, como um inflado sujeito/organismo/corpo”.

Uma das principais reivindicações das comunidades cristãs/evangélicas era a proibição do fictício kit gay e da falaciosa ideologia de gênero nas escolas, os quais, em seu ponto de vista, tinham por objetivo doutrinar xs alunxs conforme princípios ideológicos anticristãos. O seu argumento era que, ao expandir repertórios sobre desigualdades sexuais e de gênero, xs professorxs poderiam influenciar xs alunxs a se tornarem gays, lésbicas, transexuais ou a performarem qualquer outra identidade que colocasse em xeque a estrutura da família tradicional brasileira. Maranhão Filho, Coelho e Dias (2018, p. 68, grifos dxs autorxs) apontam o kit gay

\footnotetext{
${ }^{15}$ Imagem disponível em: https://veja.abril.com.br/politica/veja-a-integra-da-sentenca-de-moro-que-condenou-lula/. Acesso em: 25 out. 2020.
} 
e a ideologia de gênero como dois conceitos determinantes para a vitória de Jair Bolsonaro em 2018, pois foram eles que, através do amplo compartilhamento de notícias falsas - fake news -, incitaram a mobilização de repertórios político-religiosos voltados à identificação de "sujeitos subversivos que seriam os inimigos da "família tradicional brasileira” e que intentariam destruí-la por meio da homossexualização de crianças, da libertinagem sexual e outros elementos”. Em diálogo com essxs autorxs, acredito que o apoio de grupos cristãos/evangélicos ao projeto de poder bolsonarista revela o seu desejo perverso de manter o status quo e perpetuar a "distribuição desigual do reconhecimento e da cidadania” (MARANHÃO FILHO; COELHO; DIAS, 2018). Do contrário, por que apoiariam um candidato que flerta com práticas autoritárias e que defende políticas de desigualdade, destruição e morte? Se o seu objetivo era de fato proteger as crianças, por que se filiariam a um candidato que ensina crianças a fazer sinal de arma com as mãos (Figura 7)? Definitivamente, não é por acaso que Jair Bolsonaro tem fomentado a construção de uma aliança simbólica entre Estado e Religião no Brasil, a qual tem se mostrado uma das bases mais fortes - e sórdidas - do seu governo. Se antes a Religião parecia restringir-se ao campo privado, hoje ela parece "atua[r] sobre aquilo que se define como público, mais especificamente as normas em forma de lei ou de costumes” (ALMEIDA, 2019, p. 208).

Figura 7: Jair Bolsonaro em visita a Goiânia (2018)

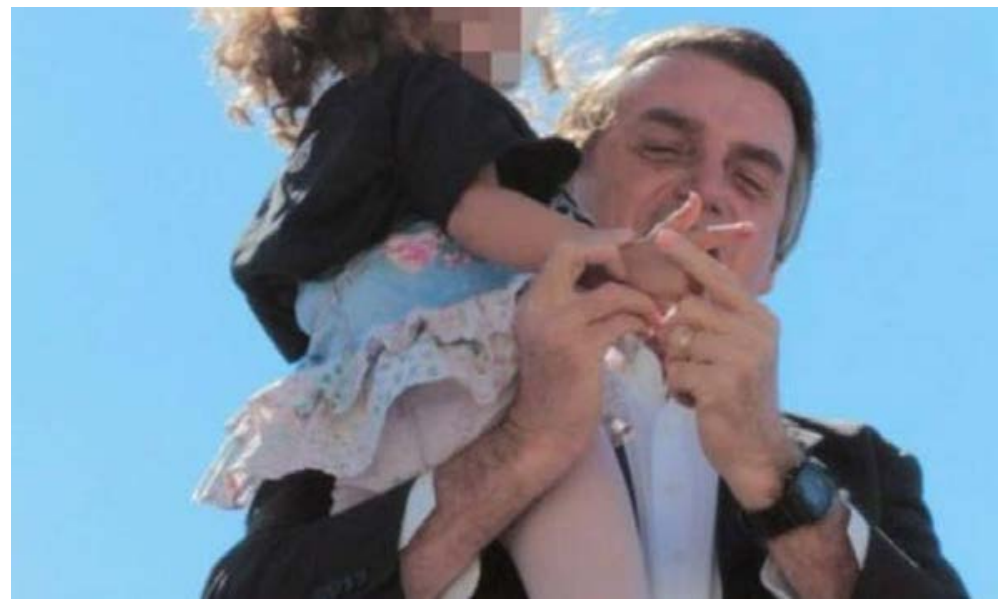

Fonte: Imagem extraída de O Globo. ${ }^{16}$

O sinal de arma com as mãos tornou-se um dos principais elementos semióticos da campanha de Jair Bolsonaro, juntamente com o ato de fala Bandido bom é bandido morto, materialidades que representam "a instrumentalização do ódio e a mobilização permanente da população para uma guerra sempre iminente” (BRANCO, 2019, p. 72). O primeiro efeito desses mecanismos foi a construção da confiança de uma parte significativa da população nas promessas de segurança do então candidato, o que era reforçado pelo seu desejo de que todo cidadão de bem no Brasil tivesse uma arma de fogo para se defender. O segundo e mais trágico efeito dos mecanismos em questão, especialmente do ato de fala Bandido bom é bandido

\footnotetext{
${ }^{16}$ Imagem disponível em: https://oglobo.globo.com/brasil/bolsonaro-ensina-crianca-imitar-arma-com-mao-22905093. Acesso em: 25 out. 2020.
} 
morto, foi a composição da imagem do cidadão de bem e do bandido em nosso imaginário, processo que teve como parâmetro o crivo social das classes dominantes. Levando em conta a dinâmica racista e cis-heterocentrada que estrutura a sociedade brasileira, assim como o conservadorismo reacionário encenado pela extrema direita (BRAZ, 2017), pode-se inferir que o sujeito indexicalizado como cidadão de bem era/é, geralmente, um sujeito branco, de classe média, cisgênero, heterossexual e que se alinha aos repertórios ideológicos bolsonaristas; ao passo que o sujeito indexicalizado como bandido era/é, na maioria das vezes, um sujeito pobre e negro - ou, pelo menos, não branco - que se contrapõe aos padrões morais endossados por Bolsonaro. Nessa conjuntura, segundo Guirado (2019), o cidadão de bem se apresenta como um sujeito que merece ser defendido, enquanto o cidadão do mal ou bandido se apresenta como um potencial inimigo da pátria. Na esteira da advogada Monique Rodrigues do Prado (2020, n.p.), acredito que a lógica perversa do ato de fala Bandido bom é bandido morto revela "o fetiche pelo punitivismo sadomasoquista naturalizado" que estrutura o imaginário racista e homotransfóbico brasileiro.

O conjunto de atos de fala que possibilitou a emergência destes tempos sombrios foi atravessado por uma série de oposições binárias, como direita-esquerda, coxinha-petralha e cristão-anticristão. O binarismo direita-esquerda promoveu uma distinção entre o grupo que apoiava e o grupo que se opunha ao impeachment/Golpe de 2016. O seu efeito mais nocivo foi a polarização radical do país, que culminou na construção de um muro de segurança na Esplanada dos Ministérios, em Brasília, para evitar possíveis conflitos entre os grupos durante as manifestações. Aquela construção, que passou a ser popularmente referida como o Muro do Impeachment, foi o artefato empírico que não apenas representou, mas legitimou a separação do Brasil em dois extremos. O elemento de maior valor indexical dentro daquele sistema binário era o alinhamento do sujeito nos enquadres do impeachment de Dilma Rousseff: se o alinhamento fosse de apoio, o sujeito era indexicalizado como membro da direita; se o alinhamento fosse de oposição, o sujeito era indexicalizado como membro da esquerda e do PT. Feita essa primeira relação, o sujeito era indexicalizado como coxinha [direita] ou petralha [esquerda/ PT], termos que passaram a constituir uma oposição binária determinante para a indexicalização política dxs brasileirxs. Como ressalta Borba (2019, p. 169), os sujeitos indexicalizados como coxinhas representavam um grupo formado majoritariamente por pessoas brancas e de classe média que estilizavam "a sua perspectiva moral e estética com símbolos nacionalistas [...] e se proclamavam os guerreiros contra a corrupção". Por outro lado, os sujeitos indexicalizados como petralhas geralmente representavam diferentes segmentos da esquerda que, embora não completamente satisfeitos com a gestão dos governos petistas, "temiam que o golpe destruísse os poucos avanços [sociais] promovidos desde 2003” (BORBA, 2019, p. 169).

Na mesma época, o binarismo cristão-anticristão começou a ser fortemente evocado para indexicalizar os sujeitos. No entanto, foi durante a campanha eleitoral de 2018 que ele se tornou um elemento estruturante da realidade brasileira, em virtude da persistente enunciação do ato de fala Deus acima de todos e do objetivo de preservar a família tradicional brasileira. Como salientam Maranhão Filho, Coelho e Dias (2018, p. 85), o cenário eleitoral de 2018 fez com que a imagem da família tradicional brasileira se tornasse "um importante capital político para políticos/as religiosos/as que se aproveitaram do imaginário social para empurrar suas agendas". Naquele contexto, ser vinculado ao espaço da direita ou da esquerda era a base que permitia indexicalizar os sujeitos, respectivamente, como cristãos/defensores da família 
ou anticristãos/inimigos da família. O então chamado esquerdista era/é, portanto, um sujeito petista, anticristão, inimigo da pátria e da família, e socialista/comunista - ambos os termos eram/são empregados intercambiavelmente pela extrema direita. Sob um viés queer, o problema dessas oposições binárias é que elas desconsideram a mútua constituição de seus elementos, além de ignorar as contradições, as indeterminações e os espaços fronteiriços de sentido que emergem dessas estruturas. Em nenhum momento, as grandes narrativas que se formaram no Brasil abriram caminho para se compreender, por exemplo, que nem toda manifestação contrária ao impeachment/Golpe indicava um posicionamento de esquerda, assim como nem todo repertório de esquerda indicava uma relação direta com a militância petista. O próprio Muro do Impeachment não dispunha de um espaço para as pessoas que estavam em dúvida sobre a destituição de Dilma Rousseff (BORBA, 2019). Isso mostra que, como todo procedimento binário, essas oposições tiveram como efeito o mascaramento de outras possibilidades de significação, estabelecendo uma única realidade possível, legítima e desejável para o Brasil.

Figura 8: Jair Bolsonaro, Michele Bolsonaro e o pastor Edir Macedo (2019)

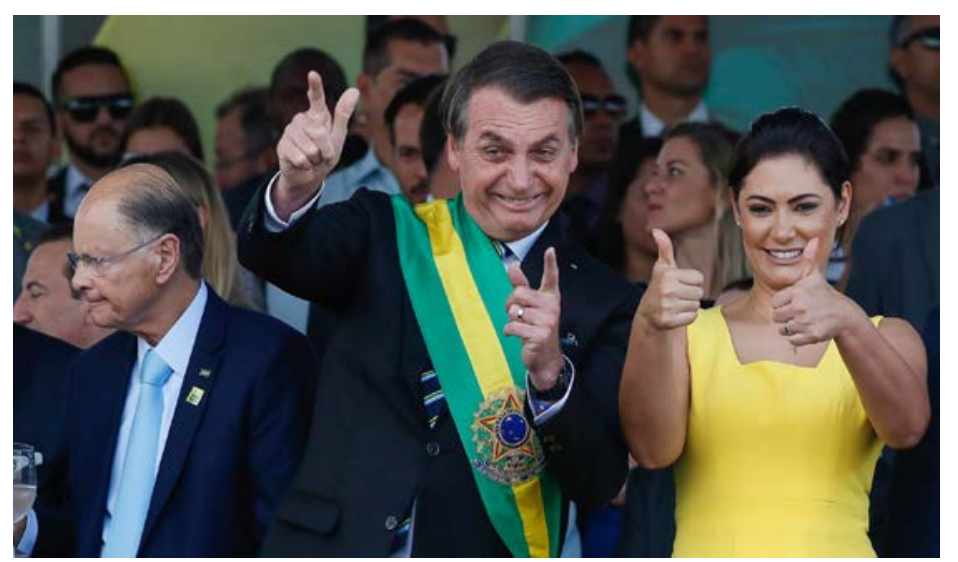

Fonte: Imagem extraída de Último Segundo. ${ }^{17}$

Tendo explorado um conjunto de mecanismos que possibilitaram a emergência destes tempos sombrios, entendo que o próximo passo da reflexão é o estranhamento de alguns atos de fala e oposições binárias que mantêm essa obscuridade. A meu ver, tais repertórios podem ser abordados levando-se em conta as duas crises que atravessam o Brasil atualmente: a crise política e a crise sanitária. No que diz respeito à crise política, pode-se compreendê-la como um prosseguimento da crise que se estabeleceu no país a partir de 2013. Trata-se, contudo, de uma continuidade radicalizada, na medida em que os seus eventos têm sido (re)articulados através de performances notadamente autoritárias.

Em março deste ano, quando a Covid-19 se espalhava pelo Brasil, eleitorxs de Jair Bolsonaro começaram a organizar manifestações, especialmente em Brasília, para demonstrar o seu apoio incondicional ao presidente. Um fato que se mostrou bastante comum nessas manifestações foi a reivindicação pelo retorno da Ditadura Civil-Militar, como mostram os seguintes

\footnotetext{
${ }^{17}$ Imagem disponível em: https://ultimosegundo.ig.com.br/politica/2020-04-09/foto-de-armas-e-xingamento-de-gado-seguidoresquestionam-tag-jairnobeldapaz.html. Acesso em: 25 out. 2020.
} 
atos de fala proferidos por manifestantes bolsonaristas: Fecha STF!; AI-5 já!; e Intervenção militar com Bolsonaro!. O efeito mais expressivo do primeiro ato de fala foi a construção de repertórios injuriosos contra investigações legalmente conduzidas pelo Supremo Tribunal Federal (STF), as quais envolvem o presidente, a sua família e aliadxs do governo. Esses repertórios, por sua vez, contribuíram para colocar em xeque a competência e a idoneidade dxs ministrxs da Suprema Corte, produzindo uma série de conflitos discursivos entre os Poderes que configuram a base do Estado Democrático de Direito. Uma das contestações mais incisivas ao Poder Judiciário diz respeito à instalação do inquérito que investiga a divulgação em massa de notícias falsas pelo chamado gabinete do ódio, que seria comandado por pessoas diretamente ligadas ao presidente da República e teria como sede o Palácio do Planalto. Talvez por isso, o ato de fala Fake news não é crime! tenha se tornado cada vez mais frequente nos espaços ocupados por apoiadorxs de Jair Bolsonaro.

Nessa linha de raciocínio, os atos de fala que materializam o desejo de intervenção militar e de retorno do Ato Institucional 5 (AI-5) podem ser compreendidos como estratégias discursivas de intimidação dxs ministrxs do STF e de incitação à desobediência civil em prol da ruptura institucional entre os Poderes Executivo e Judiciário. A ideia de uma Intervenção militar com Bolsonaro! seria importante para conferir uma roupagem legal e democrática ao possível cenário de ruptura, já que as reivindicações inconstitucionais dxs manifestantes estariam legitimadas por um presidente democraticamente eleito. Uma vez que Jair Bolsonaro participou ativamente das manifestações pró-intervenção militar em Brasília, esse respaldo não parece ser um dado fantasioso. Inclusive, no dia 19 de abril, ele chegou a discursar para dezenas de apoiadorxs em frente ao Quartel-General do Exército, cercado por cartazes e falas antidemocráticas. Em seu discurso, Bolsonaro procurou exaltar o patriotismo - Brasil acima de tudo! - e se colocar como a voz do povo brasileiro: "Todos, sem exceção, têm que ser patriotas e acreditar e fazer a sua parte para que nós possamos colocar o Brasil no lugar de destaque que ele merece" ${ }^{18}$. Conforme a lógica bolsonarista, ser patriota não significa demonstrar amor e/ou fidelidade à pátria, mas alinhar-se, incondicionalmente, aos repertórios ideológicos endossados pelo governo federal.

As trajetórias e os efeitos desses atos de fala possibilitam analisar a nossa atual crise política como uma realidade textual estruturada por três oposições binárias principais: direita-esquerda; ditadura/censura-democracia/liberdade; e mentira-verdade. Em linhas gerais, a função do binarismo direita-esquerda tem sido reatualizar os procedimentos binários que construíram a polarização do Brasil a partir de 2013 e que abriram espaço para o Golpe Parlamentar de 2016 e para o resultado das eleições de 2018. Entretanto, como as repetições nunca se dão de forma exata (DERRIDA, 1977), o elemento que mais tem sido evocado para indexicalizar politicamente os sujeitos é o seu alinhamento perante o governo Bolsonaro: se o alinhamento é de apoio, o sujeito é indexicalizado como membro da direita; se o alinhamento é de crítica, o sujeito é indexicalizado como membro da esquerda. Essa relação indexical é o ponto de partida para outros movimentos de indexicalização, entre os quais aqueles que apontam para os binarismos ditadura/censura-democracia/liberdade e mentira-verdade. Ao ser vinculado à direita, o sujeito é indexicalizado como defensor da ditadura/censura e da mentira, considerando-se os repertórios antidemocráticos mobilizados pelo presidente e por suas apoiadorxs, bem como

\footnotetext{
${ }^{18}$ Este discurso encontra-se integralmente disponível em: https://www.youtube.com/watch?v=553D8VHI8Mo. Acesso em: 25 out. 2020.
} 
as notícias falsas espalhadas pela militância bolsonarista. Em contrapartida, ao ser vinculado à esquerda, o sujeito é indexicalizado como defensor da democracia/liberdade e da verdade, tendo em vista os repertórios potencialmente democráticos articulados e/ou fomentados por grupos de oposição ao governo. O problema dessas oposições binárias é que, além de restringir o presente cenário a duas possibilidades de interpretação, camuflando a existência de outros espaços de sentido, elas tendem a ocultar a complexa disputa de significados que está em jogo no país, uma vez que tanto apoiadorxs como críticxs do governo têm se apoderado dos termos liberdade, verdade e democracia para construir os seus repertórios de (re)ação política.

Esses mecanismos discursivos, sobretudo os atos de fala evidenciados, mostram como a nossa democracia tem sido explorada para subverter o próprio sistema democrático. Afinal, como ponderam Levitsky e Ziblatt (2018, p. 17), a maioria das crises democráticas que assolam o mundo contemporâneo não decorre de golpes militares ou da tomada repentina do poder por grupos autoritários; as democracias de hoje se tornam frágeis pelas ações de governos eleitos democraticamente, os quais “mantêm um verniz de democracia enquanto [a] corroem”. Tomando por base os repertórios discursivos mobilizados por Bolsonaro e suas apoiadorxs, e considerando a lógica das políticas adotadas pelo atual governo, pode-se dizer que o projeto de poder bolsonarista reflete três dos quatro indicadores de postura autoritária elencados por Levitsky e Ziblatt (2018): rejeição das regras democráticas do jogo, o que pode ser observado nos movimentos contra as investigações legalmente conduzidas pelo STF; negação da legitimidade dos oponentes políticos, o que se revela nos movimentos autoritários contra a imprensa e aquelxs que se opõem ao governo; e tolerância ou encorajamento à violência, o que se percebe nos movimentos de exaltação do poder bélico do Estado e no desejo obsessivo de armar a população. Esse contexto nos permite compreender a atual fase da nossa crise política como o clímax da crise democrática que se instalou no Brasil a partir do Golpe de 2016, já que foi a partir da queda de Dilma Rousseff que começamos a testemunhar, de modo mais incisivo, a circulação de repertórios e práticas antidemocráticas ou democraticamente instáveis no país.

Figura 9: Manifestação antidemocrática em Brasília (abril de 2020)

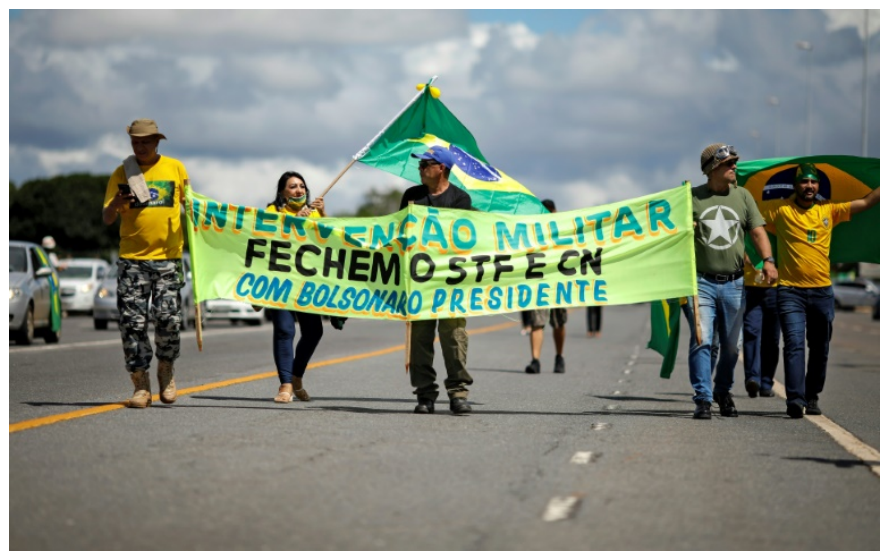

Fonte: Imagem extraída de Isto é. ${ }^{19}$

\footnotetext{
${ }^{19}$ Imagem disponível em: https://istoe.com.br/stf-investigara-ato-pro-intervencao-militar-do-qual-bolsonaro-participou/. Acesso em: 25 out. 2020.
} 
No que diz respeito à nossa atual crise sanitária, pode-se afirmar que se trata de uma consequência do alastramento da Covid-19 pelo mundo e, mais especificamente, da postura adotada pelo governo federal perante o avanço da epidemia no Brasil. Alguns dos atos de fala que se mostraram recorrentes na construção desse contexto são: Essa doença só mata idosos; É só uma gripezinha; e A economia não pode parar!. Esses três enunciados ganharam projeção após o pronunciamento ${ }^{20}$ de Jair Bolsonaro, exibido em rede nacional na noite de 24 de março deste ano. Em seu discurso, o presidente questiona o fechamento do comércio e das escolas, pois "[o] que se passa no mundo tem mostrado que o grupo de risco é o das pessoas acima de 60 anos", portanto, “[r]aros são os casos fatais de pessoas sãs, com menos de 40 anos de idade”. Mais adiante, ao referir-se à possibilidade de ele próprio ser contaminado, enfatiza: "[P]elo meu histórico de atleta, caso fosse contaminado pelo vírus, não precisaria me preocupar, não sentiria ou seria, quando muito, acometido de uma gripezinha ou resfriadinho". Foi a partir dessa performance discursiva que os atos de fala em destaque passaram a circular de forma mais intensa no Brasil, levando ao aumento exponencial de infecções e mortes por Covid-19 em todo o país. O seu principal efeito foi a minimização da gravidade da doença e da pandemia, o que desencadeou a queda progressiva do índice de isolamento social em diversas cidades/ regiões brasileiras e o descumprimento de medidas preventivas recomendadas pela Organização Mundial da Saúde (OMS) e pelas comunidades médicas e científicas (inter)nacionais.

A minimização dos efeitos da doença e a relativização da gravidade da pandemia, que perpassam todo o pronunciamento de Jair Bolsonaro, tiveram por objetivo demonstrar que, apesar das consequências da crise, a "[n]ossa vida tem que continuar”. Essa ideia serviu de base para a mobilização do ato de fala A economia não pode parar!, que acabou se tornando uma espécie de mantra para o governo federal. Um dia antes do pronunciamento de Bolsonaro, um conhecido empresário brasileiro, apoiador do governo, afirmou, em uma rede social, que "as pessoas têm que produzir" e que o Brasil não pode parar "por conta de 5.000 pessoas ou 7.000 pessoas que vão morrer". Isso porque, em suas palavras, "as consequências que nós vamos ter economicamente no futuro vão ser muito maiores”. Essa postura ideológica, notoriamente ancorada em prerrogativas neoliberais, traduz uma parte expressiva dos repertórios discursivos que passaram a ser mobilizados a partir da fala do presidente, a qual pode ser compreendida como um discurso competente, já que, como pondera Chauí (2007, p. 19), trata-se de um "discurso instituído”, cujo “conteúdo e a forma já foram autorizados segundo os cânones da esfera de sua própria competência" - afinal, estamos falando de um discurso proferido pelo representante do mais alto cargo do Poder Executivo. Os efeitos do pronunciamento de Bolsonaro vieram à tona em meados de abril, quando o nosso cenário pandêmico começou a tomar proporções trágicas. Em Manaus, por exemplo, a população viveu dias caóticos, com o sistema de saúde à beira de um colapso, ambulâncias vagando pelas ruas em busca de leitos disponíveis e pessoas doentes morrendo em casa. Duas cenas marcantes do período foram a abertura de valas comuns e a realização de sepultamentos coletivos de vítimas e/ou casos suspeitos da doença no cemitério da cidade.

Esses atos de fala produziram uma realidade estruturada por três oposições binárias principais: eu-outrx; humanx-não humanx; e economia-vida. Em relação à primeira oposição,

\footnotetext{
${ }^{20}$ Este pronunciamento encontra-se integralmente disponível em: https://www.youtube.com/watch?v=Vl_DYb-XaAE. Acesso em: 25 out. 2020.
} 
começamos, a partir de abril, a testemunhar a mobilização de repertórios e performances que apontam para a individualização dos corpos em um contexto atravessado por demandas eminentemente coletivas. Muitas pessoas passaram a exercer o seu "direito individual” de sair de casa e de não fazer uso da máscara facial em locais públicos, como se essas performances não pudessem impactar negativamente a vida de outras pessoas, e como se os seus corpos não estivessem relacionados e não significassem em correlação com outros corpos: o eu como extensão dx outrx e vice-versa. Pode-se dizer que houve um abalo representativo no que Boff (2003, p. 85, grifos meus) denomina ética do cuidado, que se expressa quando o sujeito se percebe como parte de um coletivo e minimamente responsável por sua existência, isto é, quando o eu se sente "[ligado] ao destino do outro". Paralelamente à mobilização de repertórios de empatia e solidariedade, pudemos observar a construção e a performance repetida de "um individualismo exacerbado, possessivo, uma atomização do mundo”, dificultando o exercício de uma hermenêutica compreensiva, que entenda que “[o] outro já está interiorizado no eu, é uma espécie de duplo de mim mesmo” (HERMANN, 2014, p. 482, grifos meus).

Além de expressar a individualização dos corpos, a dissociação entre o eu e o outrx expressa uma compreensão hierarquizada desses corpos em termos de humanidade, o que nos leva à segunda oposição binária: humanx-não humanx. Ao ignorarem as medidas de proteção coletiva contra a Covid-19, as pessoas parecem estar movidas, também, por uma percepção, talvez inconsciente, da irrelevância e descartabilidade da vida dx outrx, que, aos seus olhos, não se apresenta como humanx e, portanto, dignx de cuidados, deslocamentos e até mesmo de luto. Essa é uma discussão que Judith Butler vem fazendo desde 2004, quando ela passou a questionar quais corpos realmente importam e são reconhecidos como humanos na sociedade (BUTLER, 2004a, 2004b). Em seu ponto de vista, no que se refere aos cenários de disputa - ou enquadres de guerra -, o que se coloca em pauta é o reconhecimento da vida como vida, o que implica reconhecer x outrx como humanx (BUTLER, 2009). Nesse sentido, atos de fala como Essa doença só mata idosos! e estatísticas que revelam a situação de maior vulnerabilidade das pessoas pobres, negras e indígenas frente à atual crise, produzem como efeito a percepção de que algumas vidas valem menos que outras. Embora reconheçam a precariedade desses corpos, muitxs brasileirxs não os reconhecem como vidas humanas, o que produz e justifica, em partes, o seu comportamento egoísta e socialmente irresponsável.

O fato mais cruel que esta pandemia tem produzido não somente no Brasil, mas em âmbito mundial, é a disputa de quem poderá continuar respirando, já que uma parte notável dos repertórios discursivos sobre a Covid-19 parece remeter-se, de alguma forma, ao ar. Um dos sintomas mais característicos da doença é a falta de ar, que também se configura como um dos principais indicadores de complicação do quadro. Geralmente, as pessoas morrem porque não conseguem respirar. Até mesmo para nos prevenir, temos que nos submeter a certo desconforto, já que a máscara facial compromete a plena circulação do ar durante a respiração. Ou seja: da prevenção à morte, é do ar que se trata. Nesse cenário, a pergunta é: quem continuará tendo acesso a esse recurso natural que, até pouco tempo atrás, parecia ser um dos elementos mais democráticos da vida? Em relação ao isolamento social e demais medidas preventivas, poderíamos questionar ainda: quem pode se isolar? Quem possui uma casa minimamente confortável, com água tratada, energia elétrica e três refeições diárias para se isolar? Quem pode comprar máscaras e álcool em gel para proteção individual e coletiva? Quem dispõe de alternativas, como opções de entretenimento e comunicação virtual, para tornar o isolamento suportável? 
Essas perguntas nos levam à percepção de que este cenário pandêmico fez saltar aos olhos a intrínseca relação que os corpos humanos mantêm com materialidades não humanas. Basta pensar nos repertórios e performances encenadas por um sujeito que dispõe e um sujeito que não dispõe de condições básicas para se isolar e se prevenir. São realidades que inserem esses corpos em diferentes espaços de sentido e os localizam em diferentes matrizes e possibilidades de existência. Desse modo, considero que o binarismo humano-não humano deve também ser estranhado no sentido de explicitar a correlação entre corpos humanos e materialidades não humanas. Como propõem Sousa e Pessoa (2019, p. 524), talvez seja o momento de começarmos a "ver tudo de forma integrada, incorporada, isto é, entidades humanas e não humanas como afetando e sendo afetadas umas pelas outras”.

Em relação à oposição binária economia-vida, pode-se dizer que os seus repertórios passaram a estruturar o nosso imaginário sobre a atual crise sanitária a partir da circulação de atos de fala como A economia não pode parar!. Embora o presidente e demais líderes do governo tenham, por vezes, se apropriado de repertórios discursivos pró-vida, o que prevalece em suas colocações é o desejo de manter a economia funcionando a qualquer custo. Na noite do dia 25 de março, por exemplo, o presidente afirmou, em sua página do Twitter, que "[a] penas buscamos a dose adequada para combater esse mal [o vírus] sem causar um [mal] ainda maior" 21 (grifos meus). Tal afirmação nos leva a questionar: o que poderia ser um "[mal] ainda maior” que o vírus para um político e um governo que nunca se incomodaram com as desigualdades sociais no Brasil? Outro exemplo foi a declaração que teria sido feita, também em março, por Solange Vieira, integrante da equipe econômica do governo, sobre as projeções da pandemia no país: “É bom que as mortes se concentrem entre os idosos... Isso melhorará nosso desempenho econômico, pois reduzirá nosso déficit previdenciário”22. Performances discursivas como essas, aliadas à inércia do Executivo perante a elaboração de ações concretas e efetivas para o combate à pandemia, evidenciam que os repertórios pró-vida mobilizados por líderes e apoiadorxs bolsonaristas se configuram como estratégias discursivas evocadas para camuflar a real intenção do governo, que, nas palavras do colunista João Filho (2020, n.p.), é “proteger os interesses das elites que patrocinaram a eleição da extrema direita”. Nesse sentido, além de produzir a ideia de que a economia é uma atividade desvinculada da ação humana, o binarismo economia-vida produz uma estrutura hierarquizada de sentidos na qual o capital e os interesses políticos se sobrepõem à vida.

Trata-se de uma postura que, a meu ver, reflete duas lógicas perversas. A primeira é a lógica genocida, uma vez que os sentidos e as práticas mobilizadas pelo governo parecem não apenas ignorar as milhares de vidas perdidas durante a pandemia, mas tornar essas mortes um elemento estruturante do seu projeto de poder. Dessa forma, não seria infundado dizer que a política bolsonarista se revela como um exemplo não somente dos chamados fascismos sociais (SOUSA-SANTOS, 2007), mas também do sistema que Mbembe (2019) denomina necropolítica. Trata-se de um conceito que remete, grosso modo, a projetos políticos articulados com base "no interesse de destruir o máximo de pessoas e criar mundos de morte", construindo cenários em que as "populações estão sujeitas a condições de vida que lhes conferem o status

\footnotetext{
${ }^{21}$ A postagem encontra-se disponível em: https://twitter.com/jairbolsonaro/status/1242984309365051397. Acesso em: 25 out. 2020.

${ }^{22}$ Esta notícia pode ser conferida em: https://revistaforum.com.br/politica/coronavirus-assessora-de-guedes-enxergava-morte-deidosos-como-positiva-para-reduzir-deficit-previdenciario/. Acesso em: 25 out. 2020.
} 
de mortos-vivos” (MBEMBE, 2019, p. 92, grifos meus). Por sua vez, a segunda lógica refletida na postura do governo é uma lógica anticiência, visto que os sentidos colocados em circulação pelo presidente e suas apoiadorxs desafiam argumentos científicos sobre diversas questões relativas à pandemia. No que tange à questão econômica, ignora-se estudos como o de Correia, Luck e Verner (2020), que, ao analisar o contexto e os impactos da Gripe Espanhola, em 1918, conclui que as cidades que adotaram medidas mais rígidas, como o isolamento total da população, conseguiram reduzir tanto o número de mortes quanto os prejuízos econômicos. A lógica anticiência do governo Bolsonaro é tão proeminente que, de março a julho deste ano, tivemos dois Ministros da Saúde, ambos médicos, afastados do cargo porque escolheram pautar o seu trabalho em repertórios científicos. Durante o período mais crítico da epidemia, em que tínhamos mais de 1.000 óbitos por dia, o nosso Ministério da Saúde encontrava-se sob o comando interino de um general do Exército - hoje, Ministro Titular da Saúde - e de mais de 20 militares egressos das Forças Armadas.

Figura 10: Sepultamentos coletivos em Manaus (abril de 2020)

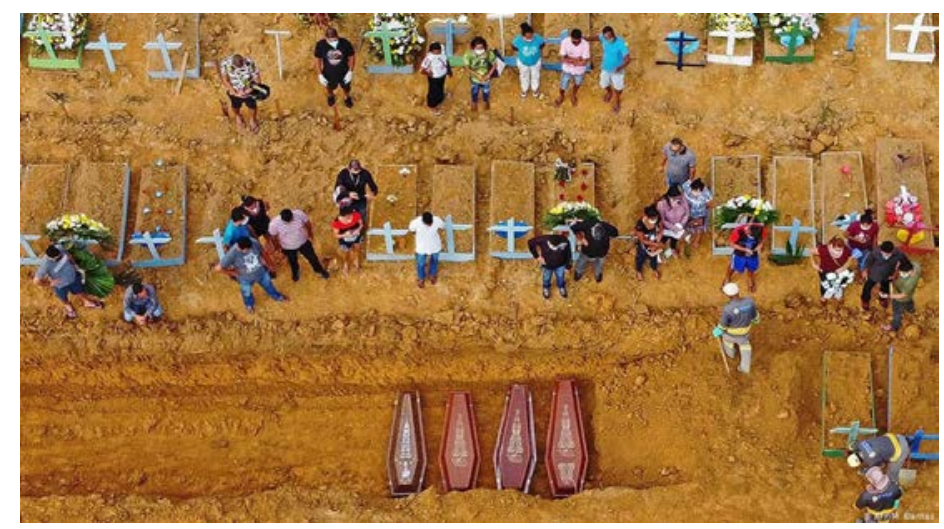

Fonte: Imagem extraída de G1 Amazonas. ${ }^{23}$

Entendo que as nossas duas crises atuais se configuram como reflexos de quatro crises que parecem estar movimentando as bases do mundo ocidental. A primeira é uma crise democrática, que se revela nos sentidos mobilizados por grupos que não se sentem mais contemplados pelas promessas da democracia tradicional e por grupos que não estão mais dispostos a negociar com outras formas de perceber a vida e de ser e estar no mundo. A segunda é uma crise ético-moral, que se observa nas constantes e violentas disputas de poder, acesso, produção e lucro potencializadas por conceitos neoliberais e que têm contribuído, sobremaneira, para uma compreensão dx outrx como objeto, um corpo descartável, uma não vida. A terceira é uma crise identitária, que se expressa nos repertórios que buscam instituir políticas identitárias únicas e permanentes em contextos atravessados por diferenças, movimentos e contradições de várias ordens. Por fim, a quarta crise, que perpassa todas as outras, é uma crise de significado, que se caracteriza pela ruptura de sentidos historicamente construídos que hoje se apresentam como territórios altamente movediços. O que é democracia? O que é liberdade? O que é verdade? O que é

\footnotetext{
${ }^{23}$ Imagem disponível em: https:/g1.globo.com/am/amazonas/noticia/2020/04/27/com-140-enterros-em-24-horas-manaus-baterecorde-de-registros-desde-inicio-de-pandemia-apenas-10-casos-sao-confirmados-de-covid-19.ghtml. Acesso em: 25 out. 2020.
} 
justiça? O que é uma vida? Feliz ou infelizmente, não dispomos de uma resposta minimamente "segura” para nenhuma dessas perguntas - se é que algum dia dispusemos.

Este cenário de crise generalizada mostra que o que chamamos de humanidade está em rota de colisão consigo mesma, levando-nos a sentir o peso de viver em uma "abstração civilizatória” (KRENAK, 2019, p. 12). Prova disso é o caso do Brasil, onde essas crises têm possibilitado observar como o mal banal (ARENDT, 2000) se instalou na vida cotidiana. Em relação à crise política, esse mal se manifesta, entre outros, nos atos de fala que clamam por intervenção militar e pelo retorno do AI-5. Como brasileirxs, sabemos que o AI-5 foi o Ato Institucional mais violento e repressivo da Ditadura Civil-Militar. Sabemos, também, como mostra o relatório da Comissão Nacional da Verdade (BRASIL, 2014), que o Regime CivilMilitar torturou e assassinou várias pessoas, incluindo crianças. O que levaria, então, um sujeito a mobilizar repertórios discursivos em prol de um sistema que reprime, tortura e extermina? Por sua vez, em relação à crise sanitária, o mal banal se expressa nos atos de fala que endossam os repertórios autoritários e a necropolítica de Jair Bolsonaro. Pensemos: o que levaria um sujeito a negligenciar o uso da máscara facial em locais públicos, mesmo sabendo que essa escolha pode colocar a existência de outros sujeitos em risco? A meu ver, grande parte das performances sociodiscursivas encenadas neste cenário se apresenta como reflexo da banalização do mal, ou seja, a prática da injúria e da violência se encontra tão naturalizada em nosso contexto que, muitas vezes, não há qualquer reflexão sobre o seu exercício e as suas consequências. O sujeito simplesmente performa o ato, como se estivesse cumprindo o dever de "criar mundos de morte" (MBEMBE, 2019, p. 92, grifos meus).

Construídas a partir de um olhar crítico embasado por praxiologias queer (JAGOSE, 1996; LOURO, 2004; MISKOLCI, 2012; SULLIVAN, 2003), as reflexões compartilhadas até aqui focalizam o papel e os (des)caminhos da linguagem na produção da obscuridade que atravessa a vida contemporânea no Brasil. Por meio do estranhamento de um conjunto de atos de fala e oposições binárias, pudemos observar que a realidade obscura que vivemos está intimamente relacionada à mobilização de um vasto e complexo repertório de enunciados e oposições racistas, sexistas, misóginas, elitistas e homotransfóbicas ancoradas em preceitos neoliberais, neopentecostais e neofascistas. São atos de fala injuriosos que ferem não somente por (re)produzir efeitos violentos na ordem social mais ampla, mas por performar a violência no próprio ato da enunciação - a linguagem como efeito (BUTLER, 1997). O estranhamento desses repertórios se deu a partir da percepção da vida social como um texto constituído por múltiplos mecanismos semióticos que, ao serem mobilizados discursivamente, produzem as realidades que supostamente descrevem. Ao explorar a vida como um artefato textual, foi possível construir uma proposta analítica da normalização sobre os repertórios que a constituem, revelando alguns mecanismos discursivos que têm produzido hierarquias e cerceamentos identitários no Brasil. Além disso, foi possível explicitar os jogos de presença e ausência (DERRIDA, 1973 [1967]), bem como a artificialidade, as contradições, as fraturas e os atravessamentos que permeiam essa realidade, o que se alinha a um projeto de desontologização radical da linguagem, dos corpos, dos sujeitos, das identidades e da própria vida (PRECIADO, 2011).

Em relação às contribuições dos letramentos queer para a elaboração crítica destes tempos, acredito que o seu maior potencial, como dito na primeira parte do ensaio, é que eles oferecem elementos para se estranhar categorias, práticas, eventos e performances que se apresentam 
como "fatos", revelando os seus mecanismos discursivos de produção e, assim, possibilitando a construção de outros repertórios de sentido. No que se refere ao contexto escolar, o que se propõe é a mobilização de práticas discursivas que abram espaço para o estranhamento de construções textuais regidas por esquemas binários de conhecimento, tal como propus anteriormente. Tratase de produzir formas de relação com a linguagem que nos estimulem a repensar os nossos modos de saber (HOOKS, 1994) e que ofereçam caminhos para contestarmos os enquadres de autoritarismo, violência e morte que estruturam a nossa realidade. Para realizar esse trabalho, xs professorxs podem se valer de múltiplos recursos semióticos - como falas, postagens, fotografias, vídeos, charges, corpos, performances, histórias/experiências de vida etc - e entrecruzar diferentes repertórios (onto)epistemológicos - saberes ocidentais e não ocidentais, acadêmicos e não acadêmicos, que fazem dialogar diferentes formas de compreensão da vida - em suas práticas, de modo a construir um corpo de saberes que desafie a lógica disciplinar imposta pela ciência moderna/colonial. Se a palavra queer remete a espaços fronteiriços de sentido (LOURO, 2004) e a “leitura de mundo é plural”, como argumenta Rezende (2020, p. 12) em alusão à Freire $(1967,1992)$, não acredito que seja possível engendrar práticas de letramentos queer em espaços disciplinares marcados pelo desejo de verdade, coerência e pertencimento.

Outro ponto que considero importante no trabalho com letramentos queer é a necessidade de se estranhar a clássica ideia de comunicação como um processo linear, homogêneo e descorporificado. A publicação da obra Curso de Linguística Geral, de Saussure (2006 [1916]), não apenas inseriu a linguística no campo da dita Ciência Moderna, como também inaugurou uma série de conceitos que até hoje permeiam o nosso imaginário sobre língua(gem). Em seu famoso circuito de fala, o autor apresenta a comunicação como uma atividade técnica, neutra e que se realiza fora das relações de poder, já que a suposta interação se dá entre dois corpos idênticos, aparentemente jovens, masculinos e caucasianos, e que compartilham os mesmos lugares socioculturais. Essa é uma ideia que pode ser facilmente desconstruída por qualquer circuito de fala da vida real, em que os sujeitos possuem traços físicos diversos, encenam performances identitárias e culturais situadas, e ocupam diferentes lugares nas estruturas de poder. Se observarmos, por exemplo, as imagens apresentadas no decorrer do ensaio, veremos que elas representam circuitos de fala bastante complexos, visto que são constituídos por sujeitos localmente situados e atravessados por diversas categorias sociais e identitárias que os posicionam em matrizes de poder específicas. Essa heterogeneidade nos permite afirmar que os processos comunicativos não envolvem a mera troca de mensagens entre sujeitos iguais, como propõe Saussure (2006 [1916]), mas, ao contrário, forjam-se em territórios organizados por múltiplas diferenças que se traduzem em constantes negociações e disputas de fala, significado e poder. Assim sendo, entendo que um dos objetivos sociopedagógicos dos letramentos queer, sobretudo em tempos sombrios como os nossos, é propiciar o engajamento de alunxs e professorxs em práticas discursivas que respondam às complexidades que caracterizam as trocas comunicativas e as negociações e disputas de sentido que permeiam a sociedade mais ampla.

Recentemente, tive a oportunidade de vivenciar duas experiências que ilustram algumas premissas do trabalho com letramentos queer. Ambas aconteceram em um Instituto de Ensino Superior que oferece cursos de formação pedagógica, segunda licenciatura, pós-graduação lato sensu, MBA e capacitação e aperfeiçoamento, em Goiânia-GO. A primeira se deu, presencialmente, em uma turma de formação pedagógica em Letras/Português-Inglês, durante as aulas do módulo Literatura Inglesa. Uma das atividades do módulo foi a leitura crítica do conto The 
Lottery - A Loteria -, da escritora Shirley Jackson (2005 [1948]). Em linhas gerais, o texto narra a história de um vilarejo em que, uma vez por ano, acontece uma loteria que envolve todas as famílias do local. O evento é conduzido pelos homens mais velhos da comunidade e vence quem tirar da tradicional caixa o papel tarjado com uma marca preta. Como "prêmio", essa pessoa recebe o "direito" de ser apedrejada até a morte pelos seus pares - até mesmo as crianças participam do ritual. Para introduzir a atividade, apresentei cinco imagens que remetem a diferentes partes da história para que xs alunxs reconhecessem os pontos mais significativos do enredo. Em seguida, assistimos a um vídeo sobre a biografia da autora para compreender o seu contexto de escrita. O principal estágio da aula foi a leitura crítica do conto, que foi realizada por meio de perguntas que buscavam estranhar a oposição binária tradição-mudança e os atos de fala que a reforçam na história. Nesse estágio, procuramos relacionar os temas do conto ao nosso atual contexto sociopolítico - como "a loteria" tem se realizado no Brasil? - e xs alunxs tiveram a oportunidade de compartilhar as suas visões e as suas experiências sobre as questões abordadas, o que abriu espaço para outros estranhamentos e para uma complexa teia de negociações e disputas de sentido sobre a vida em sociedade.

Por sua vez, a segunda experiência se deu em uma turma de formação pedagógica em Pedagogia, durante a aula remota do módulo Educação e Diversidade - de Gênero, Sexual, Religiosa e de Faixa Geracional. A primeira parte da aula foi dedicada ao estranhamento das oposições binárias eu-outrx e identidade-diferença, que foi realizado por meio da leitura do nosso atual cenário pandêmico, de imagens do ator Rodrigo Santoro e dx cantorx Pabllo Vittar, de experiências compartilhadas pelxs alunxs e da leitura crítica do texto A produção social da identidade e da diferença (SILVA, 2007). Nessa atividade, mais especificamente, buscamos mapear os desdobramentos do binarismo identidade-diferença na vida social brasileira; identificar outras oposições binárias - como brancx-negrx, homem-mulher, ricx-pobre, heterossexual-homossexual - e atos de fala que as reiteram; e analisar como esses procedimentos binários incitam práticas de violência e desigualdade. Em seguida, apresentei imagens que ilustram três acontecimentos recentes - o assassinato do adolescente João Pedro por policiais, no Rio de Janeiro; os protestos do Black Lives Matter, nos Estados Unidos; e uma manifestação antifascista organizada por times de futebol, em São Paulo - para que xs alunxs refletissem sobre como elas incorporam as nossas atuais disputas em torno do binarismo identidade-diferença. Por fim, propus uma reflexão sobre o papel da educação e do currículo escolar em contextos de disputa identitária, tendo como foco os repertórios de sentido mobilizados pelo atual governo na esfera educacional e na sociedade como um todo. Essa discussão suscitou uma série de resistências e negociações, na medida em que diversos sentidos foram contestados por meio das vivências e percepções compartilhadas pelxs alunxs.

Como se pode observar, essas experiências refletem alguns elementos que podem ser relacionados ao trabalho com letramentos queer. O primeiro deles é que, em ambas, foram articuladas práticas pedagógicas e discursivas abertas à multiplicidade, ao entrecruzamento, à ambiguidade, à contradição e ao movimento, característica que as afasta de perspectivas de letramento ancoradas em preceitos moderno-coloniais de leitura, educação e conhecimento. O segundo é que, nas duas experiências relatadas, foram utilizados diversos recursos semióticos além do texto escrito - como imagens, vídeos, corpos, falas e vivências -, bem como repertórios advindos de diferentes áreas do saber - como literatura, linguística, pedagogia, antropologia e sociologia -, o que possibilitou a construção de uma imundície praxiológica e/ou de espaços 
(onto)epistemologicamente fronteiriços em sala de aula. O terceiro elemento é que, em ambos os contextos, a comunicação foi entendida como uma atividade complexa e atravessada pela diferença, o que refletiu nos constantes processos de negociação e disputa de sentidos entre xs participantes - alunxs e professor. Finalmente, o quarto elemento é que o principal objetivo das atividades propostas foi estranhar construções textuais ancoradas em lógicas binárias de conhecimento, abrindo espaço para o desvelamento de mecanismos discursivos que as (re) produzem e para a emergência de repertórios de sentido que elas mascaram.

Tendo como referência o nosso contexto de crise, acredito que uma das contribuições mais notáveis dos letramentos queer é o seu potencial para desafiar as políticas autoritárias e a necropolítica do atual governo. Esse desafio é performado através do engajamento crítico nas disputas que têm sido travadas cultural e discursivamente no país, disputas essas que, como vimos, têm se expandido para os nossos corpos e para a nossa existência. Nesse sentido, pode-se inferir que os letramentos queer se apresentam como formas de se articular contrapolíticas a políticas institucionalizadas que ferem os nossos corpos e ameaçam os nossos direitos - à pluralidade, à igualdade e, sobretudo, à vida. Para Zembylas (2013, p. 8), a contra-hegemonia é um "processo que desafia visões normativas sobre a realidade social e política”. Entretanto, com base em escritos gramscianos, o autor pondera que os movimentos e as resistências contra-hegemônicas devem incorporar relações de afetividade, uma vez que elas pressupõem uma relação com "os corações e as mentes das pessoas, suas ações, crenças e emoções sobre o mundo” (ZEMBYLAS, 2013, p. 8). Assim sendo, compreender os letramentos queer como uma contrapolítica significa reconhecer o seu potencial para construir resistências afetivas a projetos políticos que (re)produzem enquadres de autoritarismo, violência e morte. Em outras palavras: se está em vigor uma política de destruição da vida, temos a chance de mobilizar contrapolíticas de afeto e reexistência (SOUZA, 2011).

No romance A Peste, Albert Camus (1947) narra a trajetória de uma epidemia que atinge a cidade de Oran, na Argélia. No decorrer da obra, o narrador descreve as reações da população diante da epidemia, as quais vão desde a completa apatia a mais genuína solidariedade. A grande lição da história é que as piores epidemias são as ético-morais, e não as biológicas. Por outro lado, é nos momentos de crise que muitas pessoas reavaliam a sua existência em relação a outras existências e acabam por se reconstruir humana e socialmente. Além disso, as crises podem estimular a construção de resistências aos sistemas que as produziram, o que abre espaço para questionamentos, rearticulações e mudanças. Para citar um texto recente de Sousa-Santos (2020), há sempre uma pedagogia nas crises. A pergunta que fica dessa contradição é: que ensinamentos levaremos destes tempos mais sombrios que outros, como professorxs e como corpos que habitam o mundo em relação com absolutamente tudo que o constitui? O caminho das praxiologias e letramentos queer parece ser interessante para pensar essa questão, uma vez que ele nos possibilita estranhar a vida social em seus diversos movimentos, contradições e possibilidades.

Como nenhuma repetição é exata, ainda que a história se repita, novos sentidos podem ser mobilizados em prol da justiça, da igualdade, do afeto e da não violência. Retomando a música Dark ballet, se vivemos em um mundo "em chamas”, no qual corpos são queimados pelas diferenças que eles performam e/ou por sua condição de não existência, é nosso dever 
trabalhar para que essa fogueira seja radicalmente estranhada. São tempos de luta... Afinal, ainda penso duas vezes antes de vestir uma camiseta vermelha para sair de casa.

\section{REFERÊNCIAS}

ALMEIDA, R. Bolsonaro presidente: conservadorismo, evangelismo e a crise brasileira. Novos Estudos, São Paulo, v. 38, n. 1, p. 185-213, 2019. DOI: https://doi.org/10.25091/ s01013300201900010010

ARENDT, H. Homens em tempos sombrios. São Paulo: Companhia das Letras, 1987.

ARENDT, H. Eichmann em Jerusalém - um relato sobre a banalidade do mal. São Paulo: Companhia das Letras, 2000.

AUSTIN, J. How to do things with words. Cambridge: Harvard University Press, 1975.

AVRITZER, L. Impasses da democracia no Brasil. Rio de Janeiro: Civilização Brasileira, 2016.

BOFF, L. Ethos Mundial: um consenso Mínimo entre os Humanos. Rio de Janeiro: Sextante, 2003.

BORBA, R. A linguagem importa? Sobre performance, performatividade e peregrinações conceituais. Cadernos Pagu, Campinas, n. 43, p. 441-474, 2014. DOI: https://doi. org/10.1590/0104-8333201400430441

BORBA, R. Injurious signs: the geopolitics of hate and hope in the linguistic landscape of a political crisis. In: PECK, A.; STROUD, C.; WILLIAMS, Q. (org.). Making sense of people and place in linguistic landscape. London: Bloomsbury, 2019. p. 161-181.

BORBA, R.; LOPES, A. C. Escrituras de gênero e políticas da differánce: imundície verbal e letramentos de intervenção no contexto escolar. Linguagem \& Ensino, Pelotas, v. 1, n. esp., p. 241-285, 2018. DOI: https://doi.org/10.15210/rle.v21i0.15198

BRANCO, F. C. O ódio como afeto político: sobre a construção do populismo de extremadireita no Brasil. Psicanálise \& Barroco em Revista, Rio de Janeiro, v. 17, n. 2, p. 64-95, 2019. DOI: http://dx.doi.org/10.9789/1679-9887.2019.v17i2.64-95

BRASIL, C. N. V. Relatório da Comissão Nacional da Verdade. Brasília: CNV, 2014.

BRASIL, T. I. As mensagens secretas da Lava Jato. 2019. Disponível em: https://theintercept. com/series/mensagens-lava-jato/. Acesso em: 11 jun. 2020.

BRAZ, M. O golpe nas ilusões democráticas e a ascensão do conservadorismo reacionário. Revista Serviço Social \& Sociedade, São Paulo, n. 128, p. 85-103, 2017. DOI: https://doi. org/10.1590/0101-6628.095

BUCHOLTZ, M.; HALL, K. Locating identity in language. In: WATT, D.; LLAMAS, C. (org.). Language and identities. Edinburgh: Edinburgh University Press, 2010. p. 18-28.

BUTLER, J. Gender rouble. Feminism and the subversion of identity. New York: Routledge, 1990. 
BUTLER, J. Bodies that matter. On the discursive limits of sex. New York: Routledge, 1993. BUTLER, J. Excitable speech: a politics of the performative. New York: Routledge, 1997. BUTLER, J. Undoing gender. Nova Iorque: Routledge, 2004a.

BUTLER, J. Precarious life: the powers of mourning and violence. London: Verso, 2004b. BUTLER, J. Frames of war. When is life grievable?. London: Verso, 2009.

BUTLER, J. Quando a economia se torna o berro agonizante dos eugenistas [Entrevista cedida a] Juan Dominguez e Rafael Zen. Le Monde Diplomatique, 13 maio 2020. Disponível em: https://diplomatique.org.br/quando-a-economia-se-torna-o-berro-agonizante-dos-eugenistas/. Acesso em: 26 jun. 2020.

CAMUS, A. A Peste. Rio de Janeiro: Record, 1947.

CARVALHO, C. A.; FONSECA, M. G. C. Violência em acontecimentos políticos: jornalismo e lawfare no caso Lula. Comunicação e Historicidades, São Paulo, esp. 1, p. 100-112, 2019. DOI: http://dx.doi.org/10.1590/1982-25542019441720

CHAUÍ, M. Cultura e democracia: o discurso competente e outras falas. São Paulo: Cortez, 2007. CORREIA, S.; LUCK, S.; VERNER, E. Pandemics depress the economy, public health interventions do not: evidence from the 1918 Flu. Social Science Research Network, [s. 1.], p. 1-55, 2020. DOI: https://dx.doi.org/10.2139/ssrn.3561560

CURTIN, M. L. Languages on display: indexical signs, identities and the linguistic landscape of Taipei. In: SHOHAMY, E.; GORTER, D. (org.). Linguistic landscape: expanding the scenery. New York: Routledge, 2009. p. 221-237.

DEMOCRACIA em vertigem. Direção: Petra Costa. Produção: Joanna Natasegara, Shane Boris, Tiago Pavan. [S. 1.]: Netflix, 2019. son. color.

DERRIDA, J. Gramatologia. São Paulo: Perspectiva, 1973 [1967].

DERRIDA, J. Limited Inc. Evanston: Northwertern University Press, 1977.

FILHO, J. Coronavírus: existe uma lógica genocida por trás do falso dilema entre a economia e vidas. 2020. Disponível em: https://theintercept.com/2020/03/29/coronavirus-economiavidaslogica-genocida/. Acesso em: 30 jul. 2020.

FOUCAULT, M. Power/Knowledge. New York: Pantheon Books, 1980.

FREIRE, P. Educação como prática de liberdade. Rio de Janeiro: Paz e Terra, 1967.

FREIRE, P. A importância do ato de ler - em três artigos que se completam. São Paulo: Cortez, 1992.

FREITAS, L. F. R.; MOITA LOPES, L. P. Vivenciando a outridade: indexicalidade e performances narrativas de universitários migrantes. Revista Brasileira de Linguística Aplicada, Belo Horizonte, v. 19, n. 1, p. 147-172, 2019. DOI: https://doi.org/10.1590/19846398201913696 
GUIRADO, M. Entre Discurso e Ato, há muito mais do que se imagina. Psicologia USP, São Paulo, v. 30, p. 1-9, 2019. DOI: https://doi.org/10.1590/0103-6564e190027

HARAWAY, D. Saberes localizados: a questão da ciência para o feminismo e o privilégio da perspectiva parcial. Cadernos Pagu, Campinas, n. 5, p. 7-41, 1995 [1988].

HERMANN, N. A questão do outro e o diálogo. Revista Brasileira de Educação, Rio de Janeiro, v. 19, n. 57, p. 477-493, 2014.

HOOKS, B. Teaching to transgress: education as the practice of freedom. New York: Routledge, 1994.

JACKSON, S. The Lottery and other stories. New York: Farrar, Straus and Giroux, 2005 [1948]. JAGOSE, A. Queer theory: an introduction. New York: New York University Press, 1996.

JOSSO, M. C. Experiências de vida e formação. São Paulo: Cortez, 2004.

KARNAL, L. Karnal e Cortella: reflexões em tempos de coronavírus (Entrevista cedida a) Giluia Vidale. Veja, 18 abr. 2020. Disponível em: https:/veja.abril.com.br/saude/karnalecortella-reflexoes-em-tempos-de-coronavirus/. Acesso em: 26/06/2020.

KLEIMAN, A. B. Modelos de Letramento e as práticas de alfabetização na escola. In: KLEIMAN, A. B. (org.). Os significados do letramento: novas perspectivas sobre a prática social da escrita. Campinas: Mercado de Letras, 1995. p. 15-61.

KRENAK, A. Ideias para adiar o fim do mundo. São Paulo: Companhia das Letras, 2019. LEVITSKY, S.; ZIBLATT, D. Como as democracias morrem. Rio de Janeiro: Zahar, 2018. LOURO, G. L. Um corpo estranho: ensaios sobre sexualidade e teoria queer. Belo Horizonte: Autêntica, 2004.

MADONNA. Dark ballet. In: MADONNA. Madame X. Lisboa, Londres, Los Angeles, Nova York: Interscope, 2019a.

MADONNA. Dark ballet (Official music video). 2019b. Disponível em: https://www. youtube.com/watch?v=6Uagw4zser8. Acesso em: 25 jun. 2020.

MADONNA. The World of Madame X. Lisbon: Madonna et al., 2019c. Disponível em: https://www.youtube.com/watch?v=14NrWlJ7THQ\&t=769s. Acesso em: 26 jun. 2020.

MARANHÃO FILHO, E. M. A.; COELHO, F. M. F.; DIAS, T. Biela. "Fake news acima de tudo, fake news acima de todos": Bolsonaro e o "kit gay”, "ideologia de gênero" e o fim da “família tradicional”. Revista Eletrônica Correlatio, São Paulo, v. 17, n. 2, p. 65-90, 2018. DOI: https://doi.org/10.15603/1677-2644/correlatio.v17n2p65-90

MBEMBE, A. Necropolitics. Durham/London: Duke University Press, 2019.

MELO, C. T. V.; VAZ, P. R. G. E a corrupção coube em 20 centavos. Galáxia, São Paulo, n. 39, p. 23-38, 2018. DOI: https://doi.org/10.1590/1982-255434843 
MESSENBERG, D. A direita que saiu do armário: a cosmovisão dos formadores de opinião dos manifestantes de direita brasileiros. Revista Sociedade e Estado, Brasília, v. 32, n. 3, p. 621-647, 2017. DOI: https://doi.org/10.1590/s0102-69922017.3203004

MISKOLCI, R. Teoria queer: um aprendizado pelas diferenças. Belo Horizonte: Autêntica Editora, 2012.

MOITA LOPES, L. P. Teorias queer, performatividade e ideologia linguística. 2020. Disponível em: https://www.youtube.com/watch?v=KLWlSY5FD6g\&t=1161s. Acesso em: 26 jun. 2020.

MOITA LOPES, L. P.; FABRÍCIO, B. F. Por uma 'proximidade crítica' nos estudos em Linguística Aplicada. Calidoscópio, São Leopoldo, v. 14, n. 4, p. 711-723, 2019.

MOLL NETO, R. A nação como “comunidade imaginada” nas relações internacionais: o caso das narrativas sobre o papel dos Estados Unidos diante da Revolução da Nicarágua e da Guerra Civil em El Salvador nos anos 1980. Revista Tempo do Mundo, Brasília, v. 3, n. 1, p. 283-305, 2017.

OLIVEIRA, F. F. Governo Bolsonaro e o apoio religioso como bandeira política. RevistaBrasileira de História das Religiões, Maringá, n. 37, p. 137-160, 2020. DOI: https:// doi. org/10.4025/rbhranpuh.v13i37.52231

PINTO, J. P. Performatividade radical: ato de fala ou ato de corpo. Gênero, Niterói, v. 3, n. 1, p. 101-110, 2002. DOI: https://doi.org/10.22409/rg.v3i1.260

PINTO, J. P. Conexões teóricas entre performatividade, corpo e identidades. DELTA, São Paulo, v. 23, n. 1, p. 1-26, 2007. DOI: https://doi.org/10.1590/S0102-44502007000100001

PRADO, M. R. O fetiche punitivista: bandido bom é bandido morto? 2020. Disponível em: https://conexaoto.com br/2020/02/13/o-fetiche-punitivista-bandido-bom-e-bandido-morto. Acesso em: 30 jun. 2020.

PRECIADO, B. Multidões queer: notas para uma política dos “anormais”. Revista Estudos Feministas, Florianópolis, v. 19, n. 1, p. 11-20, 2011. DOI: https://doi.org/10.1590/S0104026X2011000100002

PRONER, C. et al. (org.). Comentários a uma sentença anunciada: o processo Lula. Bauru: Canal 6, 2017.

REZENDE, T. F. Políticas e práticas interculturais de letramento. Goiânia, 2020. p. 1-20. [Manuscrito].

RITCHIE, K. Social identity, indexicaty and the appropriation of slurs. Croatian Journal of Philosophy, [s. l.], v. XVII, n. 50, p. 155-180, 2017.

ROCHA, L. L. Teoria queer e a sala de aula de inglês na escola pública: performatividade, indexicalidade e estilização. 2013. Tese (Doutorado em Linguística Aplicada) - Faculdade de Letras, Universidade Federal do Rio de Janeiro, Rio de Janeiro, 2013. 
ROSSI, M. Protestos anti-PT registram agressões a quem veste camiseta vermelha. El País, São Paulo, 17 ago. 2015. Disponível em: https://brasil.elpais.com/brasil/2015/08/17/ politica/1439769515_800304.html. Acesso em: 24 nov. 2020.

SAUSSURE, F. Curso de linguística geral. São Paulo: Cultrix, 2006 [1916].

SILVA, T. T. da. A produção social da identidade e da diferença. In: SILVA, T. T. da. (org.). Identidade e diferença: a perspectiva dos Estudos Culturais. Petrópolis: Vozes, 2007. p. 73-102.

SOUSA, L. P. Q.; PESSOA, R. R. Humans, nonhuman others, matter and language: a discussion from posthumanist and decolonial perspectives. Trabalhos em Linguística Aplicada, Campinas, v. 58, n. 2, p. 520-543, 2019. DOI: https://doi.org/10.1590/0103181353 73715822019

SOUSA-SANTOS, B. Para além do pensamento abissal: das linhas globais a uma ecologia de saberes. Novos Estudos CEBRAP, São Paulo, n. 79, p. 71-94, 2007. DOI: https://doi. org/10.1590/S0101-33002007000300004

SOUSA-SANTOS, B. A cruel pedagogia do vírus. Coimbra: Almedina, 2020.

SOUZA, A. L. S. Letramentos de reexistência: poesia, grafite, música, dança: hip-hop. São Paulo: Parábola, 2011.

SOUZA, J. A radiografia do golpe: entenda como e por que você foi enganado. Rio de Janeiro: Leya, 2016.

SULLIVAN, N. A critical introduction to queer theory. New York: New York University Press, 2003.

URZÊDA-FREITAS, M. T. Letramentos queer na formação de professorxs de línguas: complicando e subverte do identidades no fazer docente. 2018. Tese (Doutorado em Estudos Linguísticos) — Faculdade de Letras, Universidade Federal de Goiás, Goiânia, 2018.

ZEMBYLAS, M. Revisiting the Gramscian legacy on counter-hegemony, the subaltern and affectivity: toward an 'emotional pedagogy' of activism in Higher Education. Critical Studies in Teaching \& Lsssssearning, [s. l.], v. 1, n. 1, p. 1-21, 2013. DOI: https://doi. org/10.14426/ cristal.v1i1.2 